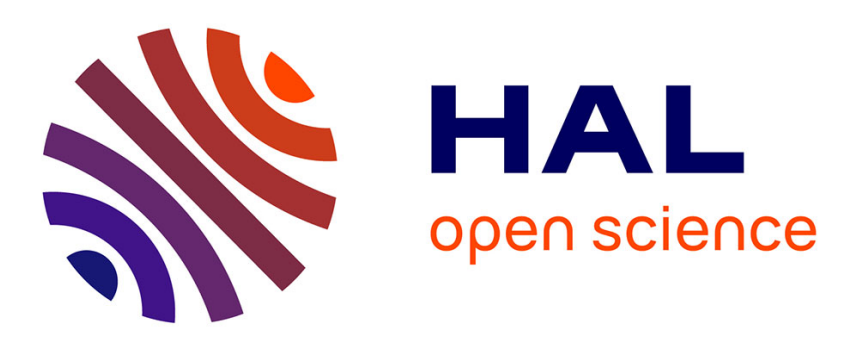

\title{
Acoustic measurements of the 1999 basaltic eruption of Shishaldin volcano, Alaska
}

\author{
S. Vergniolle, M. Boichu, J. Caplan-Auerbach
}

\section{To cite this version:}

S. Vergniolle, M. Boichu, J. Caplan-Auerbach. Acoustic measurements of the 1999 basaltic eruption of Shishaldin volcano, Alaska. Journal of Volcanology and Geothermal Research, 2004, 137 (1-3), pp.109-134. 10.1016/j.jvolgeores.2004.05.003 . hal-03280993

\section{HAL Id: hal-03280993 \\ https://hal.science/hal-03280993}

Submitted on 7 Jul 2021

HAL is a multi-disciplinary open access archive for the deposit and dissemination of scientific research documents, whether they are published or not. The documents may come from teaching and research institutions in France or abroad, or from public or private research centers.
L'archive ouverte pluridisciplinaire HAL, est destinée au dépôt et à la diffusion de documents scientifiques de niveau recherche, publiés ou non, émanant des établissements d'enseignement et de recherche français ou étrangers, des laboratoires publics ou privés. 


\title{
Acoustic measurements of the 1999 basaltic eruption of Shishaldin volcano, Alaska 1. Origin of Strombolian activity
}

\author{
S. Vergniolle ${ }^{\mathrm{a}, *}$, M. Boichu ${ }^{\mathrm{a}}$, J. Caplan-Auerbach ${ }^{\mathrm{b}, 1}$ \\ ${ }^{a}$ Laboratoire de Dynamique des Systèmes Géologiques, Institut de Physique du Globe de Paris, 4 Place Jussieu, Paris Cedex 0575252, France \\ ${ }^{\mathrm{b}}$ Alaska Volcano Observatory, Geophysical Institute, University of Alaska, Fairbanks, USA
}

\begin{abstract}
The 1999 basaltic eruption of Shishaldin volcano (Alaska, USA) displayed both classical Strombolian activity and an explosive Subplinian plume. Strombolian activity at Shishaldin occurred in two major phases following the Subplinian activity. In this paper, we use acoustic measurements to interpret the Strombolian activity.

Acoustic measurements of the two Strombolian phases show a series of explosions that are modeled by the vibration of a large overpressurised cylindrical bubble at the top of the magma column. Results show that the bubble does not burst at its maximum radius, as expected if the liquid film is stretched beyond its elasticity. But bursting occurs after one cycle of vibration, as a consequence of an instability of the air-magma interface close to the bubble minimum radius. During each Strombolian period, estimates of bubble length and overpressure are calculated. Using an alternate method based on acoustic power, we estimate gas velocity to be $30-60 \mathrm{~m} / \mathrm{s}$, in very good agreement with synthetic waveforms.

Although there is some variation within these parameters, bubble length and overpressure for the first Strombolian phase are found to be $\approx 82 \pm 11 \mathrm{~m}$ and $0.083 \mathrm{MPa}$. For the second Strombolian phase, bubble length and overpressure are estimated at $24 \pm 12 \mathrm{~m}$ and $0.15 \mathrm{MPa}$ for the first $17 \mathrm{~h}$ after which bubble overpressure shows a constant increase, reaching a peak of 1.4 $\mathrm{MPa}$, just prior to the end of the second Strombolian phase. This peak suggests that, at the time, the magma in the conduit may contain a relatively large concentration of small bubbles. Maximum total gas volume and gas fluxes at the surface are estimated to be $3.3 \times 10^{7}$ and $2.9 \times 10^{3} \mathrm{~m}^{3} / \mathrm{s}$ for the first phase and $1.0 \times 10^{8}$ and $2.2 \times 10^{3} \mathrm{~m}^{3} / \mathrm{s}$ for the second phase. This gives a mass flux of $1.2 \times 10^{3}$ and $8.7 \times 10^{2} \mathrm{~kg} / \mathrm{s}$, respectively, for the first and the second Strombolian phases.
\end{abstract}

(C) 2004 Elsevier B.V. All rights reserved.

Keywords: 1999 basaltic eruption; Shishaldin volcano, Alaska; Strombolian

\section{Introduction}

The most common explosive eruptive behaviours observed for basaltic volcanoes are periodic fire

\footnotetext{
* Corresponding author.

${ }^{1}$ Now at the Alaska Volcano Observatory, U.S. Geological Survey, Anchorage, AK, USA.
}

fountains (Hawaiian activity) or regular explosions (Strombolian activity). Both eruptive types are driven by large gas pockets, with a size on the order of the conduit radius for Strombolian explosions or much longer for Hawaiian fire fountains (Vergniolle and Jaupart, 1986). One characteristic feature is an alternating between a phase rich in gas and a phase relatively poor in gas (Jaupart and Vergniolle, 1988, 
1989; Vergniolle and Jaupart, 1990). The formation of the gas rich phase, i.e. a fire fountain for Hawaiian volcanoes and regular explosions for Strombolian volcanoes, is a consequence of small gas bubbles rising in the reservoir. These bubbles rise and accumulate at the top, where a foam layer builds. When the foam reaches a critical thickness, it collapses either totally for very fluid lava (Hawaiian case) or partially for more viscous lava (Strombolian case). The formation of a large gas pocket in the conduit leads to a fire fountain or a Strombolian explosion (Jaupart and Vergniolle, 1988, 1989; Vergniolle and Jaupart, 1990).

Understanding eruption behaviour requires a clear understanding of flow parameters, such as pressure and velocity, variables which are necessary for modeling the flow of magma and gas from depth to the surface. Because it is obviously impossible to measure these parameters directly, our best hope is to constrain these values at the surface. For a long time, however, the only estimates of physical parameters during surface activity came from visual observations, such as the height reached by ejecta (Blackburn et al., 1976; Wilson, 1980; Wilson and Head, 1981) or from studies of photoballistics (Chouet et al., 1974; McGetchin et al., 1974; Ripepe et al., 1993). For example, observations have been made of gas bubbles breaking at the surface of volcanoes such as Heimaey (Iceland) and Stromboli (Italy) (Self et al., 1974; Blackburn et al., 1976; Wilson, 1980). Using estimates of gas velocity, overpressure during Strombolian activity was estimated at $\approx 0.025 \mathrm{MPa}$ for Heimaey and at $\approx 600 \mathrm{~Pa}$ for Stromboli (Blackburn et al., 1976). Such measurements yield typical Strombolian gas velocities of less than $100 \mathrm{~m} / \mathrm{s}$ (Chouet et al., 1974; McGetchin et al., 1974; Blackburn et al., 1976), while gas velocities estimates for Hawaiian fire fountains reach 100 or $200 \mathrm{~m} / \mathrm{s}$ (Wilson, 1980; Wilson and Head, 1981; Vergniolle and Jaupart, 1990). Direct geophysical measurements of gas and ejecta velocities, during Strombolian activity, have confirmed these values either by the use of a sodar (Weill et al., 1992) or by a radar (Hort and Seyfried, 1998; Dubosclard et al., 1999, 2003; submitted) pointed towards the active vent.

Until recently, measurements of acoustic waves produced by an erupting volcano have been relatively sparse. This is primarily due to the fact that for many years low cost instruments could only measure audible frequencies (above $20 \mathrm{~Hz}$ ) (Richards, 1963; Woulff and McGetchin, 1976) and volcanic sound waves are primarily infrasonic. Recent technologies have allowed these frequencies to be recorded and show that they can be used to estimate source characteristics (Vergniolle and Brandeis, 1994, 1996; Vergniolle et al., 1996; Hagerty et al., 2000). On volcanoes, such as Stromboli (Buckingham and Garcès, 1996) or Pavlof (Garcès and McNutt, 1997), the propagation of acoustic pressure in the shallow magma and its transport towards the atmosphere has been calculated.

There are three main models that have been developed for volcanic acoustic signals. The first class of acoustic models associates the frequency and amplitude of acoustic signals with resonant modes of the shallow volcanic conduit (Buckingham and Garcès, 1996; Garcès et al., 2000; Hagerty et al., 2000). While useful for some volcanoes, a resonating conduit model, when applied to Stromboli, leads to extremely high values of viscosity $\left(9 \times 10^{5} \mathrm{~Pa} \mathrm{~s}\right)$ and source overpressure $\left(1 \times 10^{3} \mathrm{MPa}\right)$ at shallow depth (Buckingham and Garcès, 1996). At Arenal volcano (Costa Rica), an explosive source, buried at $12 \mathrm{~m}$ below the surface and with an overpressure of 3.4 MPa produces an excellent, although non-unique fit to the observed acoustic waveforms (Hagerty et al., 2000).

The second class of acoustic models suggest that sound is produced when the volcano is suddenly uncorked after reaching a pressure threshold. Uhira and Takeo (1994) suggest that the overpressure in the source is at least $0.3 \mathrm{MPa}$ at Sakurajima volcano (Japan). For Johnson et al. (1998) and Johnson and Lees (2000), Vulcanian explosions, corresponding to the disruption of a plug at the top of the magma column, are characteristic of a magma with intermediate viscosity, such as those seen at Karymsky (Kamchatka, Russia), Sangay (Ecuador) and Arenal volcanoes (Costa Rica).

In contrast, volcanoes with fluid lava, such as Stromboli, Kilauea (Hawaii), Villarica (Chile), Erebus (Antartica) keep an open vent through which large gas bubbles can escape and burst (Sparks et al., 1997). In this type of activity, sound is produced by the strong vibration of a large cylindrical bubble prior to its bursting at the top of the magma column (Vergniolle and Brandeis, 1994, 1996; Vergniolle et al., 1996). At 
137 Stromboli, acoustic data have been used to determine 138 parameters such as bubble radius $(\approx 1 \mathrm{~m})$, length 139 (between 1 and $20 \mathrm{~m}$ ) and bubble overpressure 140 ( $\approx 0.10 \mathrm{MPa}$ ) (Vergniolle and Brandeis, 1996). Be-

cause a bubble approaching an interface can develop kinematic waves whose frequency depends on viscosity, the bubble at Stromboli is also heard rising in the uppermost few tens of meters of the conduit before breaking (Vergniolle et al., 1996).

In this paper, we describe the 1999 basaltic eruption of Shishaldin volcano (Alaska, USA) during two Strombolian phases and quantify the source of acoustic signals recorded at a distance of $6.5 \mathrm{~km}$ from the vent. Acoustic data show a series of explosions, the waveforms of which are surprisingly similar to those recorded at Stromboli volcano. Therefore, the sound wave produced by each explosion is modelled, as for Stromboli, by the vibration induced by residual overpressure inside the bubble, prior to bursting at the magma surface. The best fit between the model and the explosion waveforms allows us to estimate bubble radius, length and overpressure during the course of the eruption. We show that acoustic sensors, which can give very good estimates on the gas velocity from acoustic power, are both reliable and easy to implement for volcanic monitoring.

\section{Setting and materials}

Shishaldin volcano is located on Unimak Island, the first island in the Aleutian arc (Fig. 1). Its historical eruptions have been primarily Strombolian in nature, producing steam and moderate height ash plumes of basalt and basaltic andesite. Rare instances of andesite or dacite eruptions have also been noted (Fournelle, 1988). Large volume tephra layers, whose origin might be Subplinian, are seen with an occurrence of 11 in the past $9 \mathrm{ka}$, whereas classical basaltic eruptions occur with an intermittency of $\approx 20$ eruptions/century (Beget et al., 1998; Nye et al., 2002).

In 1997, a six-station seismic network was installed near Shishaldin by the Alaska Volcano Observatory (AVO) (Fig. 1). Five of the stations are short period
160

161

162

163

165

166

167

168

169

170

171

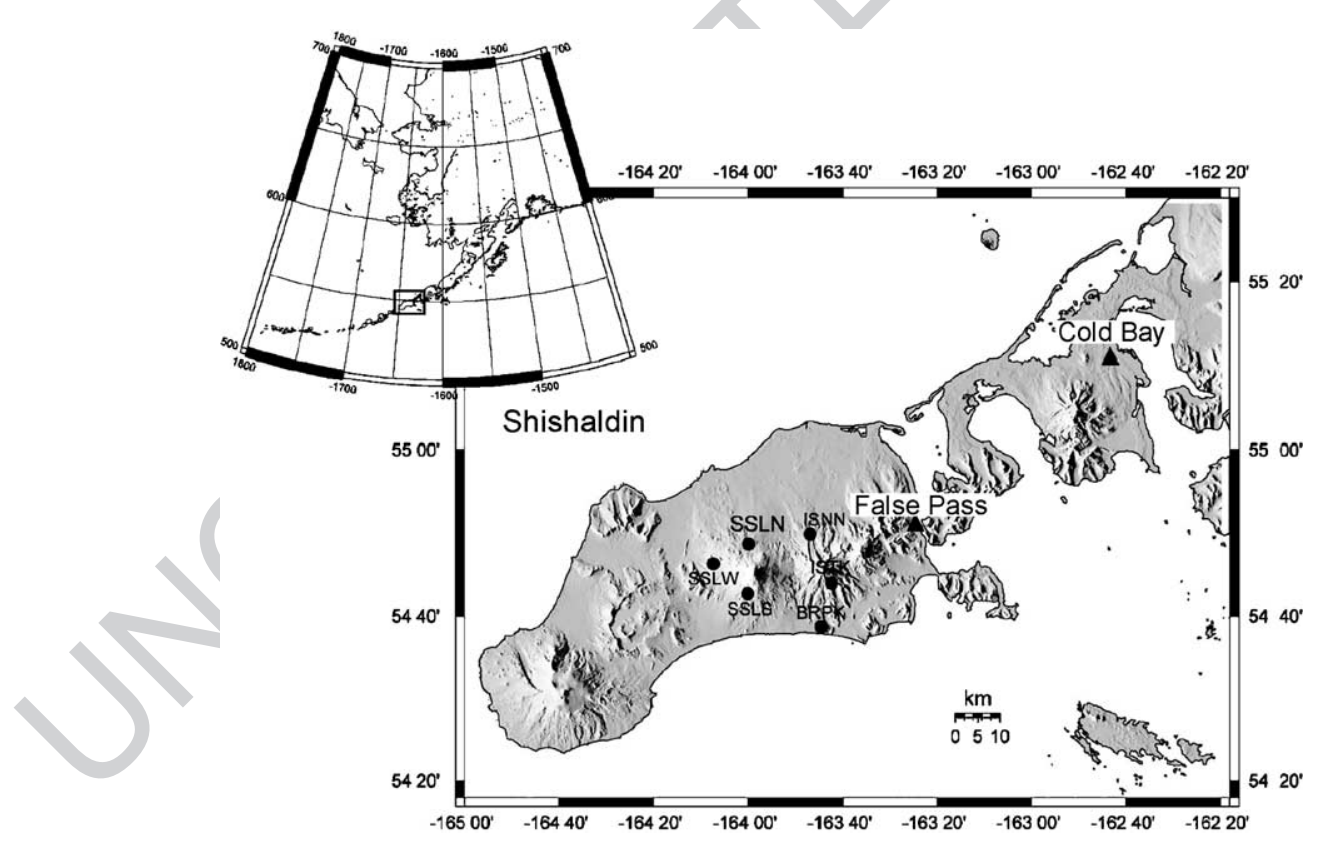

Fig. 1. Location of Shishaldin volcano and Unimak Island, Alaska. Black circles represent the locations of the short-period network operated by the Alaska Volcano Observatory. The pressure sensor used to collect the acoustic data in this study is co-located with station SSLN on the north flank of Shishaldin. The two nearest population centers, False Pass and Cold Bay, are marked with triangles. 
180 Mark Products L-4C instruments with natural period 181 of 1 s. Station SSLS is a three component Mark 182 Products L-22 instrument with 0.5 -s natural period. 183 A Setra 239 pressure sensor, with a theoretical sensi184 tivity of $0.36 \mathrm{mV} / \mathrm{Pa}$, was co-located with station 185 SSLN on the volcano's north flank and has recorded 186 signals without saturation.

187 In 1997, at the time that the pressure sensor was 188 deployed at Shishaldin, no calibration facility existed 189 at the University of Alaska Fairbanks (UAF). Conse190 quently, the instrument was nominally calibrated by 191 comparing its output to that of a calibrated Bruel and 192 Kjaer microphone (Garcès et al., 2001, pers. com.). At 193 this time the sensitivity was found to be $\approx 0.2 \mathrm{mV} /$ $194 \mathrm{~Pa}$. Unfortunately, the reference microphone was only 195 calibrated at high frequencies $(\geq 1 \mathrm{~Hz})$, with uncali196 brated sources used at lower frequencies. Attempts to 197 calibrate-minimise the instrument when it was re198 trieved in 2003 were unsuccessful due to an apparent 199 fault within the pressure sensor. Because both of these 200 calibrations were non-ideal, in this paper we use the 201 theoretical sensitivity of $0.36 \mathrm{mV} / \mathrm{Pa}$. Neither of the 202 calibrations was able to obtain the full frequency and 203 phase response, so we assumed that the instrument is 204 flat at all frequencies (the manufacturer's specifica205 tions). The theoretical transfer function for the pres206 sure sensor, telemetry system and digitizer is flat for 207 frequencies $\leq 4 \mathrm{~Hz}$ (Fig. 2).

208 Although the calibration introduces uncertainty 209 into the true amplitude of the recorded signals, the 210 initial calibration is of the same order of magnitude as 211 the theoretical one. Signal amplitudes would be 1.8

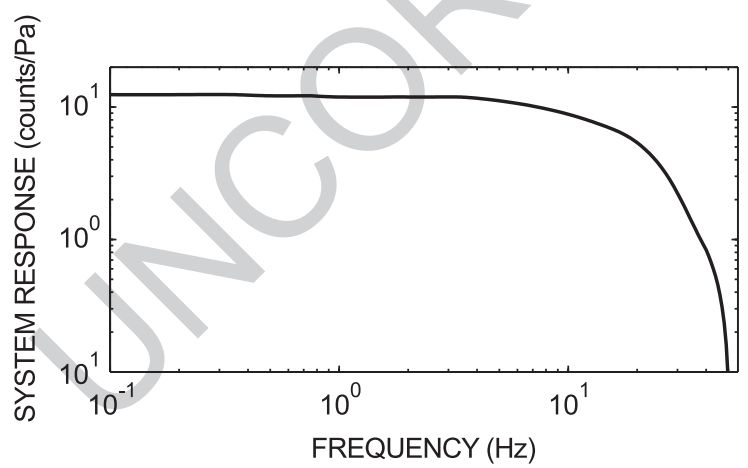

Fig. 2. Theoretical transfer function for the pressure sensor, telemetry system and digitizer. Note that the response is flat for all frequencies below $\approx 4 \mathrm{~Hz}$. times greater for the case of a sensitivity of $0.2 \mathrm{mV} /$ $\mathrm{Pa}$. Thus, while the values presented here carry an associated uncertainty, they may also be recognized as a conservative estimate. While the specific quantities inferred from these models carry this associated uncertainty, our interpretation of the sequence of events is unaffected. Thus, we feel that in spite of the lack of precise calibration, our conclusions are reasonable and merit presentation. The theoretical transfer function for the pressure sensor, telemetry system and digitizer is flat for frequencies $\leq 4 \mathrm{~Hz}$ (Fig. 2).

In the field, the pressure sensor was installed in a plastic box and mounted on the wall of the fiberglass hut in which batteries and electronics were also housed. The reference port was covered with a prophylactic membrane (M. Garcès, highly pers. com., 2003) so that the port was protected from dirt or snow. A pipe from the active port (diameter of $\approx 1 \mathrm{~cm}$ ) ran from the casing through the leeward wall of the hut, where it was positioned $\approx 15 \mathrm{~cm}$ above the hut flange, directed toward the ground to further minimise the effects of wind.

Data from all instruments are telemetered to Cold Bay or King Cove and then to AVO over analog telephone lines. Finally the data are low-pass filtered with a corner frequency of $20 \mathrm{~Hz}$ and sampled at 100 $\mathrm{Hz}$ with 12-bit resolution. Although the anti-aliasing filter diminishes signal amplitudes at high frequencies, this effect is minimal at frequencies $\leq 4 \mathrm{~Hz}$, the frequency band in which most of the data discussed here are found.

The nearest weather station to Shishaldin is stationed in Cold Bay (Fig. 1), over $90 \mathrm{~km}$ from the volcano. Moreover, it is likely that a volcano the size of Shishaldin has a significant effect on the local wind field. Consequently, wind conditions at the pressure sensor site were unknown at the time of the eruption. However, an unidentified low frequency $(0-3 \mathrm{~Hz})$ signal bearing little to no resemblance to the waveforms recorded at the time of the eruption was commonly recorded on the pressure sensor. This signal was observed both before and after the eruption, suggesting that its source was non-volcanic, and possibly due to wind. However, we were careful to consider wind as a potential source for each of the signals recorded during the eruption as well. 


\section{Eruption activity}

Although tremor and satellite thermal anomalies 262 indicated unrest at Shishaldin as early as January 263 1999, the first confirmation of eruptive activity was 264 not made until April 18, 1999. At this time, AVO 265 researchers performed an overflight of the volcano. 266 Although a thick cloud obscured Shishaldin's summit, 267 imagery acquired with a Forward Looking Infrared 268 Radiometer (FLIR) shows the first confirmed spatter269 ing activity, with ejection of lava $\approx$ several tens of 270 meters above the crater wall (Nye et al., 2002). After $27112 \mathrm{~h}$ of apparent quiet, a series of tiny bursts were 272 detected by the pressure sensor. This phase, referred to 273 as the "hum" lasted $13 \mathrm{~h}$ and was followed by a 274 dramatic increase in seismic tremor accompanied by 275 an ash plume to heights above $16 \mathrm{~km}$ (Caplan-Auer276 bach and McNutt, 2003). This Subplinian eruption is 277 believed to be responsible for the majority of ejecta 278 produced by Shishaldin in 1999 (Stelling et al., 2002). 279 The Subplinian phase was immediately followed by 280 the first major Strombolian phase, lasting $3.5 \mathrm{~h}$. 281 Explosions recorded during this phase have mean 282 frequencies near $0.7-0.8 \mathrm{~Hz}$ and mean amplitudes 283 of $1-2 \mathrm{~Pa}$ at $6.5 \mathrm{~km}$ from the vent. Two small bursts 284 of Strombolian activity occurred 2 and $7 \mathrm{~h}$ after the 285 first major Strombolian phase. Because these corre286 spond to bubbles just at the limit of detection and they 287 occurred for only a short time $(<1 \mathrm{~h})$, they will be 288 ignored here. After $35 \mathrm{~h}$ of quasi-quiescence, the 289 second Strombolian phase began and lasted almost $29024 \mathrm{~h}$ (April 22-23, 1999). These events have power 291 spectral peaks near $1.1-1.5 \mathrm{~Hz}$. For the first $17 \mathrm{~h}$ of 292 this phase, explosions have amplitudes of 0.5-4 Pa. 293 During the final $4 \mathrm{~h}$ of this phase, acoustic pressure 294 increased dramatically, with peak amplitudes exceed295 ing $30 \mathrm{~Pa}$ (Caplan-Auerbach and McNutt, 2003). 296 After this Strombolian phase, the eruption decreased 297 in intensity. However there were several ash plumes in 298 April (23rd, 26th) and May (13th, 25th, 26th) before 299 the eruption definitively ended.

300 Most of the following interpretation of the erup301 tion is based on data from the pressure sensor, co302 located with station SSLN at $6.5 \mathrm{~km}$ from the vent 303 (Fig. 1). The first acoustic signals that can be 304 definitively associated with the eruption were 305 recorded after the observed spattering activity on 306 April 18, 1999. All of the nearest seismic stations, including the station co-located with the pressure sensor (SSLN; Fig. 1), were saturated by strong tremor during most of the eruption, making it difficult to directly compare seismic and acoustic signals (Caplan-Auerbach and McNutt, 2003). The other seismometers provide qualitative information on the frequency spectra inside the volcanic edifice. All this information is combined to produce a complete understanding of the 1999 Shishaldin eruption, despite the difficulties associated with accessing such a remote site. In this first paper, we shall discuss the two Strombolian phases and estimate gas volume and pressure at the vent. In a series of papers, we interpret the pre-Subplinian (Vergniolle and CaplanAuerbach, 2003a, this issue),trends in gas velocity (Vergniolle and Caplan-Auerbach, 2003b, submitted 3 ), the Subplinian phase (Vergniolle and CaplanAuerbach, 2003c, submitted 4) and propose a general mechanism to explain the chronology of the entire 1999 Shishaldin eruption (Vergniolle and CaplanAuerbach, 2003d, submitted 5).

\section{Bubble vibration model}

During Strombolian activity, the gas pocket is released by foam coalescence at depth and rises in the volcanic conduit. Its violent formation at depth causes an excess of pressure inside the large bubble, resulting in strong initial oscillations (Vergniolle, 1998). The bubble takes a finite time to rise through the conduit, and its motion might be expected to generate acoustic or seismic energy. However, at Shishaldin, the frequent bursting of bubbles at the surface, with inter-event times of less than $10 \mathrm{~s}$, prohibits us from identifying the low amplitude signals associated with bubble rise. Furthermore, the seismic traces were saturated by strong seismic tremor, so seismic signals resulting from bubble rise are also impossible to distinguish. Due to the large liquid viscosity, the long newly formed bubble, rising in a conduit, does not have enough time to equilibrate its internal pressure to the decreasing pressure field (Vergniolle, 1998). When it reaches the top of the magma column, an excess of pressure is kept inside the "about to break" bubble and strong volumetric oscillations at the magma surface ensue. The amplitude of oscillations results in the radiation of sound 
352 waves (Vergniolle and Brandeis, 1996; Vergniolle, 353 2003). The extreme similarity between the waveforms 354 for explosions recorded at Stromboli and Shishaldin 355 volcanoes suggests that the same mechanism is at 356 work (Fig. 3).

\subsection{Qualitative description}

Bubbles of several meters in diameter have been observed bursting at the vent at Etna (Coltelli et al., 1998; T. Pfeiffer's photograph, pers. com., 2001). However, the bursting, i.e. the connection of magmatic gas to atmosphere, of such large bubbles produces frequencies around $150 \mathrm{~Hz}$ for a radius of $1 \mathrm{~m}$ and 30 $\mathrm{Hz}$ for a radius of $5 \mathrm{~m}$ by analogy to the balloon bursting problem (Temkin, 1981; Vergniolle and Brandeis, 1994). Because frequencies recorded at Shishaldin volcano are $\approx 1 \mathrm{~Hz}$, we propose that its sound is produced by the vibration of a shallow metric bubble prior to bursting, rather than by the popping

noise (Vergniolle and Brandeis, 1994, 1996). Any bubble in an infinite liquid oscillates easily: inertia causes the bubble to overshoot its equilibrium radius and the compressibility of gas, through the internal gas pressure, acts like a restoring force (Batchelor, 1967; Leighton, 1994). The experimental study of Kirpatrick and Lockett (1981) indicates that bubbles moving at speeds approaching the terminal velocity upon reaching the free surface, tend to come to rest and bounce a couple of times before bursting. Here, since the bubbles are coming from the depth of the reservoir, their rise speed had enough time to reach its equilibrium value and the bubble vibration at the top of the magma column, which is the volume mode, is the most likely phenomenon to explain the peak in acoustic pressure. Here, we assume that the oscillations are set up by a sudden overpressure inside a large bubble reaching the magma-air interface.

We approximate the bubble shape by a hemispherical head and a cylindrical tail, as expected in slug-
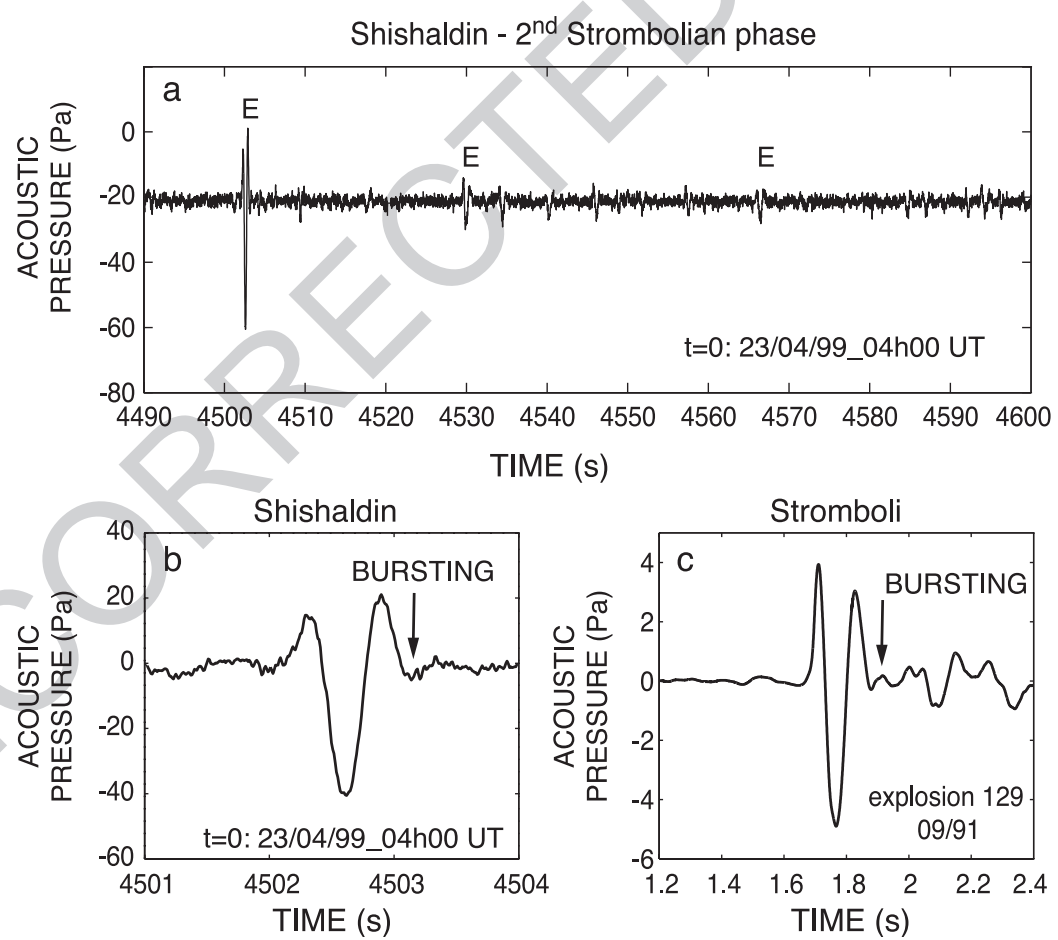

Fig. 3. Time series for Strombolian explosions at (a,b) Shishaldin and (c) Stromboli. E marks where explosions occur. The extreme similarity between the two waveforms encourages us to apply the same acoustic model for both volcanoes. Note that frequencies are different, $\approx 1 \mathrm{~Hz}$ at Shishaldin and $\approx 9 \mathrm{~Hz}$ at Stromboli. Data in figure a are raw and the mean value of acoustic pressure is removed in figure $b$. 
flow (Fig. 4). If the lava is close to the surface, as it is the case at Shishaldin (Dehn et al., 2002), no external limitation exists on bubble growth when the bubble reaches the surface and breaks in the much larger area of the crater (Fig. 5).

Although most vents are seen to be funnel shaped (Sparks et al., 1997), the precise shape of the vent at Shishaldin is not well known, and thus we do not consider its exact geometry. We also neglect the amplification of the sound inside a short tube and the distortion due to its propagation from the source to the microphone, as we have shown they are small when recording close to the source (Vergniolle and Brandeis, 1994, 1996). At Shishaldin, there is line-ofsight viewing from the summit to the location of the pressure sensor, and the crater wall is lower in that direction, allowing direct acoustic propagation.

While we cannot rule out the possibility of echoes from the crater walls, the extreme similarity between Shishaldin explosive signals and those observed at other volcanoes suggests that echoes did not contribute significantly to the time series. At the time of Strombolian activity, thermal anomalies in satellite imagery confirm that there was a significant amount of lava within the summit crater (Dehn et al., 2002), suggesting that the bubbles burst near the top of the conduit, and thereby minimising the effects of propagation within the conduit itself.

Because the distance between vent and measurements site is relatively large, about 20 times the wavelength, we have to consider the effects of the propagation of the sound wave in a stratified atmosphere. Because the atmosphere is stratified, the sound speed varies with height and there are regions, at 10-

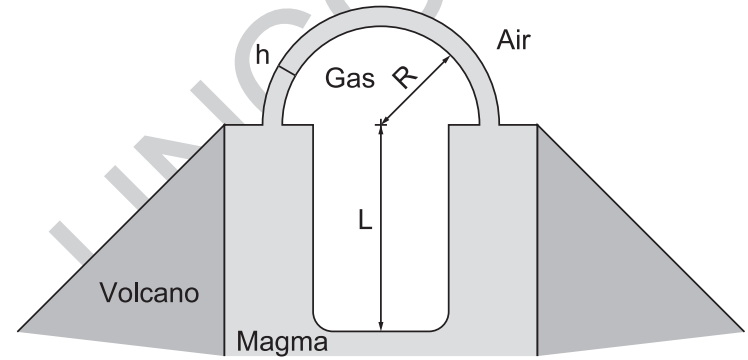

Fig. 4. Sketch of a vibrating bubble at the top of a magma column. $R, L$ and $h$ are, respectively, bubble radius, length and thickness of the magma layer above the bubble.

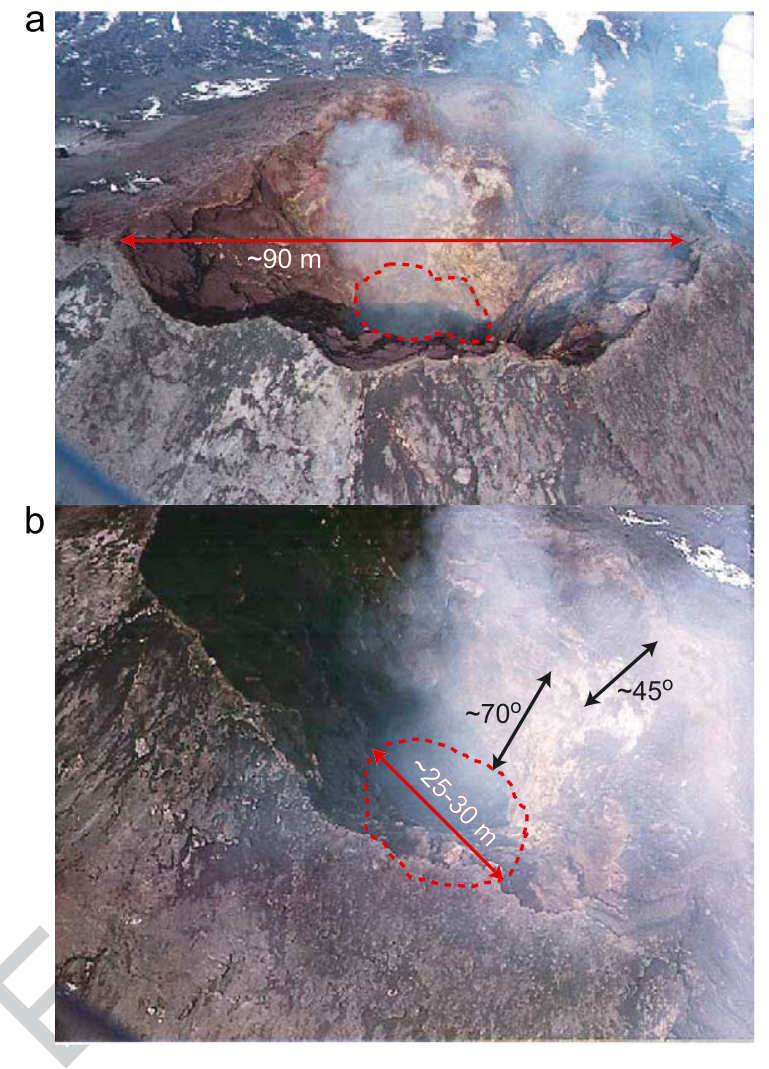

Fig. 5. Two photographs of Shishaldin vent taken by P. Stelling (AVO) during an overnight flight of the 16 August 1999.

20 and $70-90 \mathrm{~km}$ elevation, in which the sound speed is minimum (Garcès et al., 1998a,b). These regions can trap waves and propagation occurs along these ducts without the radial attenuation of a monopole. At Shishaldin, we are concerned with acoustic waves generated at an elevation of $2.85 \mathrm{~km}$ above sea level and recorded at $6.5 \mathrm{~km}$. Therefore, a spherical wave reaching the pressure sensor, can attain a maximum height of $9.25 \mathrm{~km}$ into the atmosphere, well below the low-velocity zones. Although the addition of a wind field introduces anisotropy in the infrasonic propagation, a wind blowing opposite to the direction of the wave propagation is simply to reduce the effective sound speed (Garcès et al., 1998a,b). Since we will show in next section that the sound speed is $\approx 340$ $\mathrm{m} / \mathrm{s}$ and the radiation approximately that of a monopole, we feel confident that atmospheric effects are not significant. Finally, the aforementioned similarity between Shishaldin explosions and acoustic signals 
444 recorded at Stromboli, Etna, Erebus and other volca445 noes is a compelling reason to believe that the wave446 forms are not significantly affected by wind or 447 atmosphere.

448 A Strombolian bubble reaching the surface is half 449 way immersed into the magma and half way in air, 450 despite a thin layer of magma above it (T. Pfeiffer's 451 photograph, pers. com., 2001; Fig. 4). Because of the 452 large difference in viscosity between air and magma, 453 the motion of the immersed part of the bubble is 454 restricted (Vergniolle and Brandeis, 1994, 1996). 455 Therefore, bubble vibration is entirely concentrated 456 into its hemispherical cap: the magma-air interface 457 vibrates as the bubble does. The thickness of the layer 458 of magma is likely to be of the order of magnitude of 459 the average diameter of the ejecta, as observed on 460 large bursting bubbles. Ejecta, usually a few centi461 meters thick, are much smaller than the radius of the 462 bubble, which is on the order of 1-5 m (Vergniolle 463 and Brandeis, 1994, 1996). Hence, we will consider 464 this layer as a membrane. The temperature inside the 465 bubble is chosen to be $1323 \mathrm{~K}$ (the approximate 466 temperature estimated by Dehn et al. (2002) at the 467 time of Strombolian activity) and the magma will be 468 assumed Newtonian. To estimate the viscosity of 469 Shishaldin magmas, we use geochemical data from 470 Stelling et al. (2002)and Kware MAGMA software 471 (Wohletz, 2001). Using a temperature of $1323 \mathrm{~K}$ and a 472 water content of $1.5 \mathrm{wt} . \%$ we estimate a viscosity of $473500 \mathrm{~Pa} \mathrm{~s}$. Neither uncertainties on the temperature or 474 viscosity plays a major role in the bubble dynamics at 475 the air-magma interface.

\subsection{Equations}

The source of sound is a thin layer of magma, 479 pushed by a variation of internal pressure inside the 480 bubble (Vergniolle and Brandeis, 1996). We have 481 shown for Stromboli that the source is a monopole 482 as its amplitude decreases inversely proportional to 483 the distance between the microphone and the vent 484 (Vergniolle and Brandeis, 1994). Similar analysis at 485 Shishaldin is not possible since the network includes 486 only a single pressure sensor. However, we examined 487 the amplitude of ground-coupled airwaves on the 488 Shishaldin seismic network and found that, to first 489 order, the amplitudes of these waves are inversely 490 proportional to distance from the vent. So we feel confident that these explosions are also monopolar and do not propagate into one of the ducted channels of the stratified atmosphere. In this case, the excess pressure depends on the rate of mass outflow from the source, $\dot{\mathrm{q}}$ (Lighthill, 1978). Acoustic pressure $p_{\mathrm{ac}}$ emitted at the source at time $t$ will reach the microphone, at a time $t+r / c$, where $r$ is the distance $r$ from the vent and $c$ the sound speed in air equal to $340 \mathrm{~m} / \mathrm{s}$, as determined by the moveout of airwaves arriving at the various Shishaldin seismic stations. For such a radiation, analogous to a monopole, the excess pressure $p_{\mathrm{ac}}-p_{\text {air }}$ at time $t$ is (Lighthill, 1978):

$$
\begin{aligned}
p_{\text {ac }}-p_{\text {air }} & =\frac{\dot{q}(t-r / c)}{4 \pi r} \\
& =\frac{\mathrm{d}^{2}}{\mathrm{~d} t^{2}}\left[\frac{4 \pi R^{3}(t-r / c)}{6}\right] \frac{\rho_{\text {air }}}{2 \pi r}
\end{aligned}
$$

where $\rho_{\text {air }}$ is air density equal to $0.9 \mathrm{~kg} / \mathrm{m}^{3}$ at an elevation of $2850 \mathrm{~m}$ (Batchelor, 1967). Note that factor 2 in the farthest right hand-side of the equation accounts for radiation in a halfspace, whereas a factor of 6 represents half a spherical bubble. Therefore, acoustic pressure is exactly that of a monopole.

The bubble vibrates as a thin membrane of thickness $h$. Its head grows but remains spherical with a radius $R$, the normal mode being assumed for simplicity and favored during the bubble expansion. The part of the bubble which remains in the cylindrical tube has a length $L$ (Fig. 4). Hence, the bubble has a volume $V_{\mathrm{g}}$ equal to

$V_{\mathrm{g}}=\frac{2 \pi R^{3}}{3}+\pi R_{\mathrm{o}}^{2} L$

where $R_{\mathrm{O}}$ is the initial radius. Note that in the following, indexes $\mathrm{o}, \mathrm{g}$ and eq refer to initial conditions, gas and equilibrium values, respectively. The high viscosity of magma impedes any significant drainage by gravity of the magma above the bubble, during the short time allowed for the bubble to vibrate. The volume of magma above the bubble is conserved and the liquid stretches, following the variations in bubble radius

$R^{2} h=R_{\mathrm{eq}}^{2} h_{\mathrm{eq}}$.

Because heat transfer inside large bubbles is adiabatic (Plesset and Prosperetti, 1977; Prosperetti, 528 
$R=R_{\mathrm{eq}}(1+\varepsilon)$

549 with

$R_{\mathrm{eq}}=\left(\frac{3}{2}\right)^{1 / 3}\left[\left(\frac{2 R_{\mathrm{o}}^{3}}{3}+R_{\mathrm{o}}^{2} L\right)\left(1+\frac{\Delta P}{p_{\text {air }}}\right)^{1 / \gamma}-R_{\mathrm{o}}^{2} L\right]^{1 / 3}$. bubble rise within a viscous magma or its violent formation at depth (Vergniolle, 1998, 2001).

The initial radial acceleration, $\ddot{\varepsilon}_{\mathrm{o}}$ is equal to:

$\ddot{\varepsilon}_{\mathrm{o}}=\frac{\Delta P R_{\mathrm{o}}^{2}}{\rho_{\mathrm{liq}} R_{\mathrm{eq}}^{3} h_{\mathrm{eq}}}$.

The second initial condition to be specified is the initial radius $\varepsilon_{\mathrm{o}}$ :

$\varepsilon_{\mathrm{o}}=\frac{R_{\mathrm{o}}}{R_{\mathrm{eq}}}-1$

Radial acceleration is maximum when the strong vibration starts and, therefore, the initial radial velocity is equal to zero. These initial conditions correspond to a bubble close to its minimum radius.

Bubble radius, velocity and acoustic pressure are calculated for a typical bubble present during the initial period of the second Strombolian phase. For a bubble radius of $5 \mathrm{~m}$, a length of $24 \mathrm{~m}$ and an overpressure of $0.15 \mathrm{MPa}$, the maximum velocity is $30 \mathrm{~m} / \mathrm{s}$ (Fig. 6). The magma above the bubble starts with a thickness of $0.8 \mathrm{~m}$ when the oscillation is set up into the bubble and reaches a minimum at $0.08 \mathrm{~m}$. Damping due to the viscosity, $\mu=500 \mathrm{~Pa} \mathrm{~s}$, is very small (Fig. 6c). The first absolute minimum in acoustic pressure corresponds to the maximum bubble expansion $(R \approx 15.4 \mathrm{~m})$ and the second following zero in acoustic pressure to the minimum radius (Fig. $6 \mathrm{~d})$. Note that the non-linearity of the equations result in an asymmetry between the positive and the negative peak and that acoustic pressure, which depends on acceleration as well on velocity, is at its minimum close to the maximum radius.

The bubble vibration can have a large amplitude and cases are reported where maximum radius is twice the equilibrium radius when the bubble collapse, occurring near its minimum radius, is modelled (Leighton, 1994). Here, at Shishaldin, although the change in bubble radius is large, the maximum radius, $\approx 15.4 \mathrm{~m}$, is less than twice the equilibrium radius, $\approx 11.3 \mathrm{~m}$ during the second Strombolian phase (Fig. 6a).

\subsection{Description of the model}

Direct observations of large bubbles at the top of the magma column are very sparse because the lava is 1998, 2001). Therefore, the overpressure at the surface can be viewed as a consequence of either the 

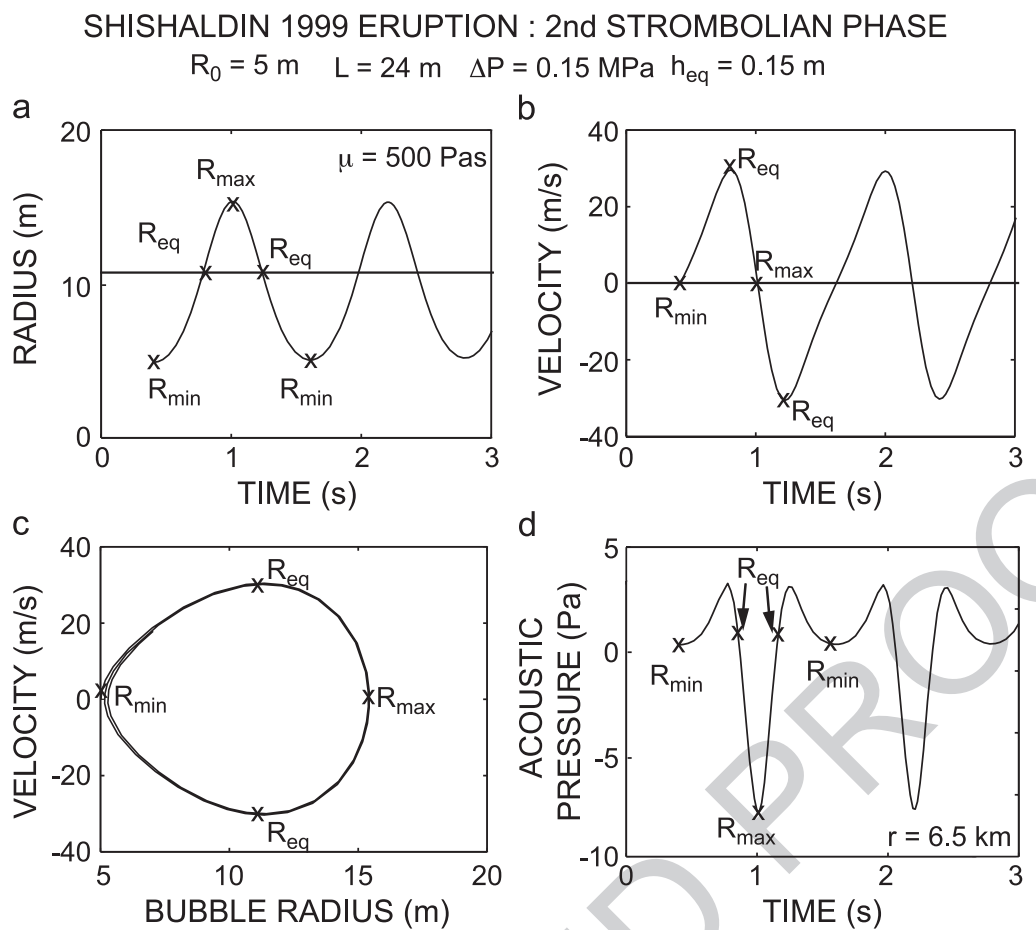

d

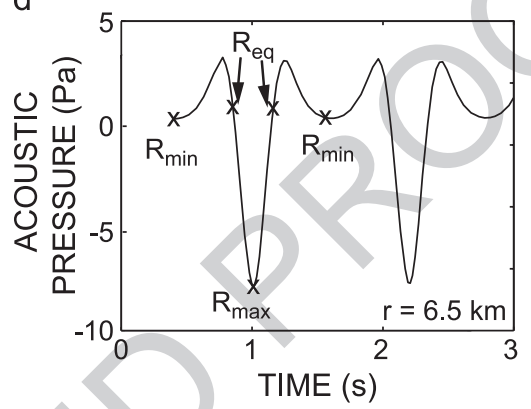

Fig. 6. Time evolution for a characteristic bubble of initial radius $R_{0}=5 \mathrm{~m}$, length $L=24 \mathrm{~m}$, overpressure $\Delta P=0.15 \mathrm{MPa}$, equilibrium thickness above bubble $h_{\mathrm{eq}}=0.15 \mathrm{~m}, \mu=500 \mathrm{~Pa}$ s. Oscillations start at time equal to $0.4 \mathrm{~s}$. (a) Bubble radius (m). (b) Bubble radial velocity (m/s). (c) Bubble velocity $(\mathrm{m} / \mathrm{s})$ as a function of bubble radius $(\mathrm{m})$. (d) Acoustic pressure recorded at $6.5 \mathrm{~km}$ from the vent $(\mathrm{Pa})$.

611 rarely visible at the vent and because viewing such 612 activity is typically dangerous. Although Blackburn et 613 al. (1976) report some bubbles at Heimaey and 614 Stromboli, the short duration of the bubble vibration 615 cycle at the interface, probably between 0.1 and $1 \mathrm{~s}$, 616 makes identification of this vibration difficult at best. 617 Furthermore, the large bubbles present during Strom618 bolian activity are probably of two different types. 619 Strombolian bubbles are those which form in the 620 magma chamber and consequently arrive at the top 621 of the magma column with some residual overpres622 sure. These are strongly overpressurised, break while 623 producing large ejecta velocities and cannot be safely 624 observed. The second type of large bubble corre625 sponds to those formed by local and slow coalescence 626 in the conduit, and has no significant overpressure at 627 the top of the magma column. Although they are 628 difficult to see on acoustic records, due to their lack of 629 gas overpressure, they may correspond to the bubbles 630 observed popping at the vent, which are safe to 631 observe.
Our model for the sound produced at the vent during the Strombolian phases is based on the assumption that the large bubble, lying just below the top of the magma column, is suddenly set with an initial gas overpressure at time $t$ equal zero. Although this assumption is a simplification, once the bubble rises from depth, its internal pressure is never at its equilibrium because the bubble is continuously exposed to a lesser external pressure and the viscosity of the liquid delays the return to equilibrium (Vergniolle, 1998, 2001). As the bubble approaches the top of the magma column, the pressure release increases on the gas inside the bubble, leading to the build-up of a viscous overpressure inside the large bubble (Vergniolle, 1998). Furthermore the formation of the large bubble at the depth of the reservoir from foam coalescence (Jaupart and Vergniolle, 1988, 1989) is violent and an initial overpressure is set in the bubble when it starts rising in the conduit (Vergniolle, 1998). At Stromboli, the initial overpressure at the approximate depth
632 
653 of $300 \mathrm{~m}$, is of the order of $11 \mathrm{MPa}$ (Vergniolle, 654 1998) in agreement with seismic studies (Chouet et 655 al., 2003). However calculations of the exact phys656 ical behaviour of the large bubble close to the top of 657 the magma column are very complex and are left to 658 further studies.

659 There are many papers which discuss the behaviour 660 of a pulsating bubble in a infinite liquid (Leighton, 661 1994). Our equations are fairly similar to Rayleigh662 Plesset equations (Plesset and Prosperetti, 1977; 663 Prosperetti, 1986; Leighton, 1994), although they 664 are adapted for the vibration of a bubble close to 665 an interface between a liquid (magma) and a gas (air 666 at atmospheric pressure). In these papers, the scaling 667 for the oscillation amplitude is done on the bubble 668 maximum radius, but our scaling on its equilibrium 669 radius is strictly equivalent (Eq. (4)). A bubble 670 pulsating at finite amplitude, as here with the max671 imum dimensionless radius $\varepsilon \approx 0.36$ (Eq. (4)), is 672 clearly a non-linear oscillator as shown by its trajec673 tory phase (Fig. 6c). There is an obvious asymmetry: 674 while in expansion the amplitude of the bubble wall 675 displacement has no absolute limit, in compression 676 the radial displacement of the wall from equilibrium 677 cannot be greater than the equilibrium radius 678 (Leighton, 1994). Surface tension and viscosity have 679 a significant effect on the dynamics of microbubbles 680 but are less effective in maintaining a spherical shape 681 for the large Strombolian bubbles described here. 682 Consequently, the bubbles experience shape distor683 tions and oscillations due to overshooting (Leighton, 684 1994). At Shishaldin, the shape of the large bubble is 685 confined by the conduit walls to be cylindrical with 686 a nose whose shape results from the potential flow of 687 liquid around its tip (Batchelor, 1967; Wallis, 1969). 688 Furthermore, the large viscosity of the magma 689 around the bubble slows down the potential defor690 mations and the initial overpressure, existing in the 691 bubble once oscillations are set, favors a spherical 692 bubble cap during its expansion.

693 Large bubbles have been produced by underwater 694 chemical explosions using explosive charges and the 695 largest charge can generate a bubble with a maximum 696 radius of $10 \mathrm{~m}$. The maximum radii of bubbles 697 produced by underwater nuclear explosions are of 698 the order of $100 \mathrm{~m}$ (Leighton, 1994). After expanding 699 to their maximum size as a result of an explosion, the 700 bubbles oscillate at least for several cycles before reaching the sea surface (Batchelor, 1967; Leighton, 1994). For underwater explosions, the resulting bubble oscillates for a few cycles between a minimum radius of $5 \mathrm{~m}$ and a maximum of $18 \mathrm{~m}$ (Cole, 1948). We envision a similar mechanism for Shishaldin bubbles, although there the origin of oscillations is obviously quite different.

Our model assumes that the magma above the bubble has a constant volume during the duration of one cycle, i.e. $\approx 1 \mathrm{~s}$. However, the thin liquid film above the bubble is both pulled down by gravity and slowed down by the viscous force within the film of magma. For simplicity and although the bubble nose is half a sphere, we assume that the flow occurs on a vertical wall by gravity, providing a maximum bound on the drainage velocity $V_{\mathrm{dr}}$. The free fall of a thin liquid film of thickness $\delta$ onto a vertical solid wall has a velocity of (Wallis, 1969)

$V_{\mathrm{dr}}=\frac{\rho_{\mathrm{liq}} g \delta^{2}}{3 \mu}$

where $\mu \approx 500 \mathrm{~Pa} \mathrm{~s}$ is the magma viscosity at Shishaldin and $\rho_{\text {liq }} \approx 2700 \mathrm{~kg} / \mathrm{m}^{3}$ the magma density. The characteristic drainage time $\tau_{\mathrm{dr}}$ is the ratio between the characteristic bubble radius $R_{\mathrm{o}} \approx 5 \mathrm{~m}$ and the drainage velocity based on the equilibrium thickness $\delta \approx h_{\text {eq }}$.

$\tau_{\mathrm{dr}}=\frac{R_{\mathrm{o}}}{V_{\mathrm{dr}}}$.

Although the drainage velocity is largely overestimated, the drainage time $\tau_{\mathrm{dr}}$ is larger than $12.6 \mathrm{~s}$ for an equilibrium thickness $h_{\mathrm{eq}}=0.15 \mathrm{~m}$. This is one order of magnitude above the characteristic time for vibration, $\approx 1 \mathrm{~s}$, confirming that drainage is therefore negligible during the bubble vibration at the top of the magma column.

Acoustic measurements suggest that a Strombolian bubble sustains one cycle of oscillation before breaking. This is possible if the radial stress $\sigma_{\text {rr }}$ and the tangential stresses $\sigma_{\theta \theta}$ and $\sigma_{\phi \phi}$ do not exceed the mechanical strength of the magma. For a bubble of radius $R_{\mathrm{O}}$ surrounded by a thin magma shell of thickness $h_{\text {eq }}$, the stresses are

$\sigma_{\mathrm{rr}}=\Delta P_{\mathrm{g}} / 2$ 
742 and

$\sigma_{\theta \theta}=\frac{\Delta P_{\mathrm{g}} R_{\mathrm{o}}}{2 h_{\mathrm{eq}}}$

745 where $\Delta P_{\mathrm{g}}$ is the gas overpressure (Landau and Lif-

746 shitz, 1986), here assumed to be equal to the initial gas

747 overpressure, $\Delta P$. The smallest of the three stresses are

748 the tangential ones, equal to $25 \mathrm{MPa}$, for the maximum

749 overpressure recorded during the two Strombolian

750 phases, $\approx 1.4 \mathrm{MPa}$, a bubble radius of $5 \mathrm{~m}$ and a film

751 thickness of $0.15 \mathrm{~m}$. Because the tensile strength of

752 magma, $320 \mathrm{MPa}$ (Dingwell, 1998), is more than 10

753 times larger than the applied stress, the magma layer

754 above the Strombolian bubbles at Shishaldin is me-

755 chanically stable and will not fail. Therefore, the

756 bubble can vibrate and does not pop. The model of

757 bubble vibration before breaking is in excellent agree-

758 ment with the measured frequency, which is more than

759 bursting balloon, i.e. a bubble whose liquid film is stretched beyond its elasticity towards bursting. Furthermore, the simplified model for a balloon bursting produces a waveform of the acoustic pressure, which corresponds to a N-Wave, i.e. with both a very strong rising time and the same amplitude for the positive and negative peaks (Temkin, 1981). These two features are not observed in the Shishaldin acoustic record.

The second mechanism by which such a large and overpressurised bubble can break is by developing instabilities at the magma-air interface or the magma-bubble interface. If the gas-liquid interface is a plane surface, the interface is stable only when the acceleration is directed from the liquid to the gas phase. However, the stability of a spherical surface depends not just on its acceleration but on its velocity: during bubble growth the streamlines diverge and produce a stabilising effect, while the reverse happens during contraction (Plesset and Mitchell, 1956; Leighton, 1994). Although the bubble nose is only half a sphere,
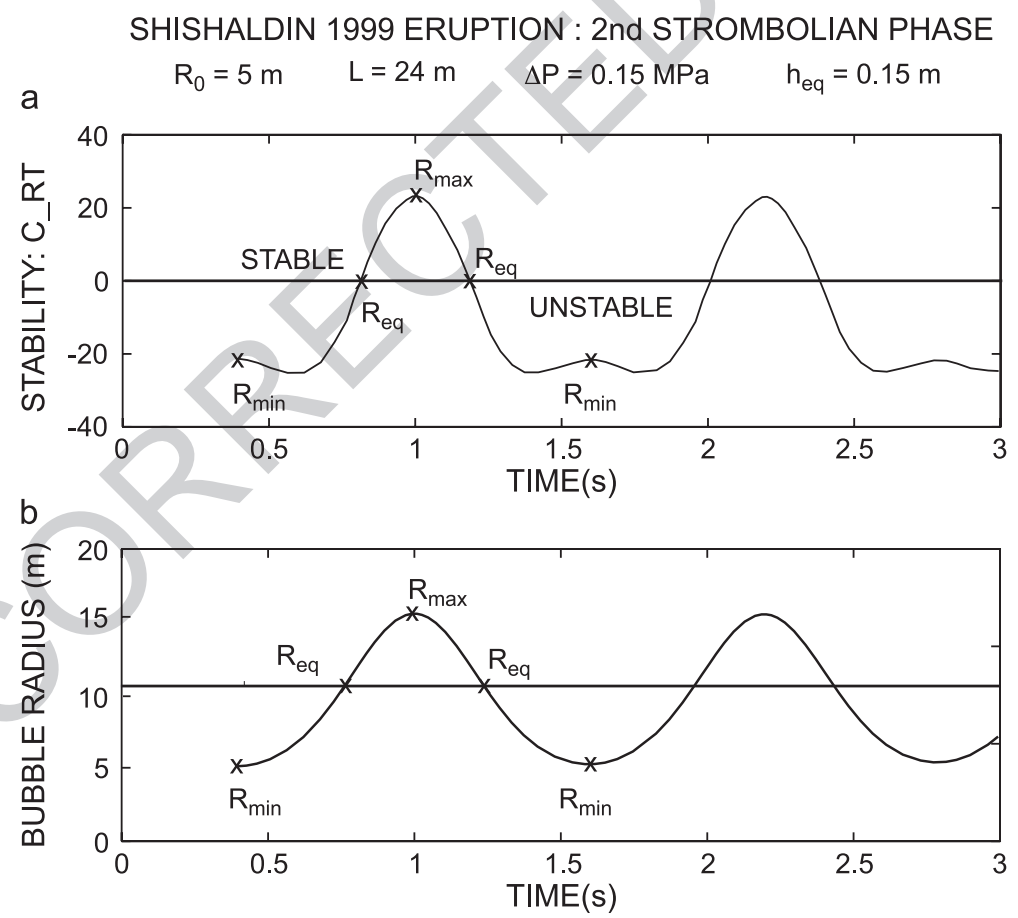

Fig. 7. (a) Stability of the bubble wall interface and (b) bubble radius ( $\mathrm{m}$ ) in time (s) for a typical bubble of the second Strombolian phase, with initial bubble radius $R_{0}$ of $5 \mathrm{~m}$, bubble length of $24 \mathrm{~m}$ and initial overpressure of $0.15 \mathrm{MPa}$. Magma thickness above bubble $h_{\mathrm{eq}}$ is $0.15 \mathrm{~m}$ and magma viscosity $\mu$ is $500 \mathrm{~Pa}$ s. Oscillations start at time equal to $0.4 \mathrm{~s}$ and the bubble wall interface is unstable if the coefficient $C_{\mathrm{RT}}$ is negative, i.e. around the minimum radius. 
780 we use the stability analysis for a sphere and the bubble 781

$$
\begin{aligned}
C_{\mathrm{RT}}= & \frac{(n-1)(n+1)(n+2) \sigma}{\rho_{\mathrm{liq}} R_{\mathrm{o}}}-\frac{3 \dot{R}}{4 R_{\mathrm{o}}^{2}} \\
& -\frac{(2 n+1) \ddot{R}}{2 R_{0}}
\end{aligned}
$$

782 is greater than zero. $n$ is the order of the harmonic, $\sigma$ the 784 surface tension, $R_{\mathrm{o}}, \dot{R}$ and $\ddot{R}$ are, respectively, the 785 bubble radius, bubble radial velocity and bubble radial 786 acceleration (Plesset and Mitchell, 1956; Leighton, 787 1994). The surface tension term, with $\sigma \approx 0.36 \mathrm{~kg} / \mathrm{s}^{2}$ 788 for a basaltic magma at $1200{ }^{\circ} \mathrm{C}$ and $0.1 \mathrm{MPa}$ (Prous789 sevitch and Kutolin, 1986; Proussevitch and Sahagian, 1996), can be ignored for bubbles as large as a few meters. The perturbation of a spherical surface would remain small for $1 \geq R / R_{\max } \leq 0.2$ and will become violent for $R \cdot R_{\max } / 10$. For a typical bubble of the second Strombolian phase, of radius, length and overpressure of respectively $5 \mathrm{~m}, 24 \mathrm{~m}$ and $0.15 \mathrm{MPa}$, the bubble is potentially unstable for about $1 \mathrm{~s}$ around its minimum radius (Fig. 7). Although the bubble also appears unstable for the first $0.4 \mathrm{~s}$, this is a consequence of assuming that the bubble oscillation is set at time zero by a sudden overpressure. The ratio between the minimum and the maximum radius, $\approx 0.3$, shows that the instability, occurring close to the minimum radius, is mild for Shishaldin bubbles. Although viscous effects will delay the growth of the instability occurring on the bubble wall near its minimum radius, acoustic data shows that the bubble vibration probably lasts just slightly more than one cycle.

\section{Generation of synthetic waveforms}

Two main periods of Strombolian activity at Shishaldin volcano were recorded by the pressure sensor: on April 19 from 20:26 h to midnight (first Strombolian phase) and from 12:00 $\mathrm{h}$ the $22 \mathrm{nd}$ of April to 12:00 h the 23rd of April (second Strombolian phase). During the quiet period in between, some signals, also attributed to breaking bubbles, were detected (Thompson et al., 2002; Caplan-Auerbach and McNutt, 2003) but are ignored here due to poor signal strength.
Due to the enormous quantity of explosions, we selected the largest explosion during a given time period for waveform modelling. This period was taken as $400 \mathrm{~s}$ for the first Strombolian phase and $800 \mathrm{~s}$ for the second one, for a total of 29 and 106 analysed explosions respectively. For each selected explosion of the two Strombolian phases, a best fit between a synthetic waveform and acoustic measurement is performed manually. In generating synthetic waveforms there are four parameters that are adjusted to determine the best fit model: bubble radius, magma film thickness, bubble length and bubble overpressure. Of these parameters, we choose to fix the values for bubble radius and magma film thickness at 5 and $0.15 \mathrm{~m}$, respectively, allowing bubble length and overpressure to vary. The comparison between model and data is extremely good for the first cycle of bubble vibration and is not valid after the bubble bursts (Fig. 8). Here, we discuss the assumptions associated with these parameters and the effect on our results of varying them.

5.1. Thickness of the magma layer, $h_{\text {eq }}$, above bubble

In previous studies of Strombolian explosions, the thickness of magma above the vibrating bubble, $h_{\mathrm{eq}}$,

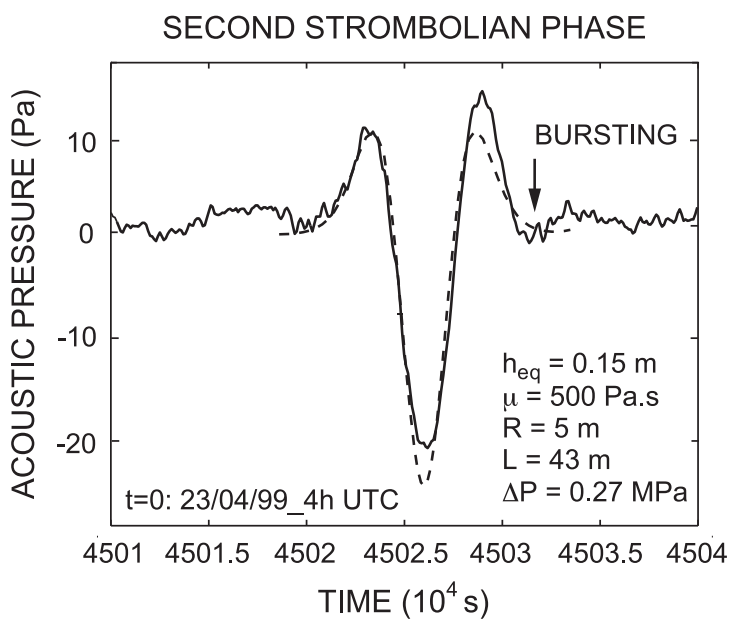

Fig. 8. Comparison between measurements of acoustic pressure (plain line) and synthetic waveform (dashed line) for one explosion of the second Strombolian phase. The synthetic acoustic pressure is produced by a bubble of radius $R_{0}=5 \mathrm{~m}$, length $L$ of $43 \mathrm{~m}$ and an overpressure $\Delta P$ of $0.27 \mathrm{MPa}$. Bubble bursting probably occurs after one cycle of vibration. 
844 has been scaled by the average diameter of ejecta 845 (Vergniolle and Brandeis, 1996). Photographs of 846 magmatic bubbles breaking at the surface of magma, 847 are in very good agreement with this assumption. At 848 Stromboli, this has lead to very reasonable values of 849 bubble overpressure, and length, between 2 and 20 850 times the bubble radius, as expected for slug flow 851 (Wallis, 1969). At Etna, a value of $h_{\mathrm{eq}}=0.1 \mathrm{~m}$ gives 852 very reasonable results for the bubble length and 853 overpressure (Vergniolle, 2003). Shishaldin deposits, 854 however, yield few clues as to the size of the Strom855 bolian ejecta. Maximum clast sizes in Shishaldin 856 tephra samples range from $0.5-22 \mathrm{~cm}$ (Stelling et 857 al., 2002), but no distinction can be made between 858 deposits ejected during the Strombolian and Subpli859 nian phases. Synthetic waveforms, however, suggest 860 that a value of $0.15 \mathrm{~m}$ is appropriate for Shishaldin 861 explosions, an approximation that we investigate 862 below.

863 Since we have little information on the size of 864 Strombolian ejecta, and hence the thickness of the 865 magma layer above the bubble, we assume that the 866 equilibrium thickness is the same for all bubbles 867 during the two Strombolian phases. Synthetic wave868 forms are very sensitive to the thickness of magma 869 above the breaking bubble because it represents the 870 mass of the oscillator. At Shishaldin, using a thickness 871 of magma outside of the range $0.1-0.2 \mathrm{~m}$ leads to 872 unreasonable values of either bubbles length and 873 overpressure. For example, a typical explosion of 874 the second Strombolian phase can be fit by using a 875 film thickness of $0.15 \mathrm{~m}$ and a bubble radius, length 876 and overpressure of respectively $5 \mathrm{~m}, 24 \mathrm{~m}$ and 0.15 $877 \mathrm{MPa}$ (Fig. 6). If the film thickness is doubled, the 878 bubble radius and length are halved to 2.5 and $10 \mathrm{~m}$, 879 respectively. However, the initial overpressure is mul880 tiplied by 6 , giving $0.9 \mathrm{MPa}$ at the vent, which is more 881 typical of an explosive volcano than one with an open 882 conduit. Thus, a $0.30 \mathrm{~m}$ thick film would require 883 unrealistic overpressures for this phase. Secondly, the 884 radial oscillation of the bubble cap can only be excited 885 when the thickness of the liquid above the bubble is 886 small compared to its radius, so the bubble can 887 produce a dome over the liquid. For a film of 888 equilibrium thickness of $0.3 \mathrm{~m}$, the magma thins from 8891.5 to $0.11 \mathrm{~m}$ for a bubble radius of only $2.5 \mathrm{~m}$ (Fig. 890 9) invalidating the requirement that the film is small 891 compared to the bubble radius.
Finally, although a thickness $h_{\text {eq }}$ equal to $0.2 \mathrm{~m}$ matches most of the explosions, it failed for the relatively "highest" frequencies measured on the 23rd of April. A value of $h_{\mathrm{eq}}$ equal to $0.1 \mathrm{~m}$ can produce a reasonable match between synthetic waveforms and measurements but leads to extremely long bubbles, of a length above 20 times the radius. We have no observations favouring extremely long bubbles, since fire fountaining was not observed during the Strombolian phases. Therefore, a value of $0.15 \mathrm{~m}$ for the magma thickness above each bubble, $h_{\text {eq }}$, is chosen for all explosions at Shishaldin volcano.

Because the bubble breaks when its radius is close to its minimum value, the liquid film is at its largest, with a value close to $0.8 \mathrm{~m}$ when the bubble breaks. However, since the mechanism of breaking is related to an instability, the size of the ejecta will probably be of the order of the wavelength of the instability, i.e. of the order of the equilibrium thickness and not its maximum thickness. Thus, there is no conflict with the thickness of the film at the breaking point and the size of the ejecta.

\subsection{Constraints on bubble radius}

Laboratory experiments show that in well-developed slug flow, bubbles occupy a large portion of the conduit (Jaupart and Vergniolle, 1988, 1989). Consequently, unless the shape of the conduit changed significantly during the eruption, it is reasonable to expect that the bubble radius would remain approximately constant throughout the 1999 eruption.

Synthetic waveforms modelling Shishaldin bubbles suggest that all of the bubbles have a radius of $\approx 5 \mathrm{~m}$. A bubble radius of $5 \mathrm{~m}$, and a conduit of $6 \mathrm{~m}$, is supported by observations of the top of the Shishaldin conduit. Photographs taken in August 1999 and July 2003, during overflights of the vent (Fig. 5) show the top of a vertically walled conduit, the radius of which is estimated to be $\approx 12-15 \mathrm{~m}$. In the latter flight, the shadow of the helicopter on the crater wall was used as a measuring tool to constrain the vent radius. In both instances, only the top several meters can be seen in the photo (Fig. 5), but we assume that it tapers at depth and has a funnel shape as most of the observed vents (Sparks et al., 1997). Our estimate of a $6 \mathrm{~m}$ radius is also consistent with direct observations of active vents 

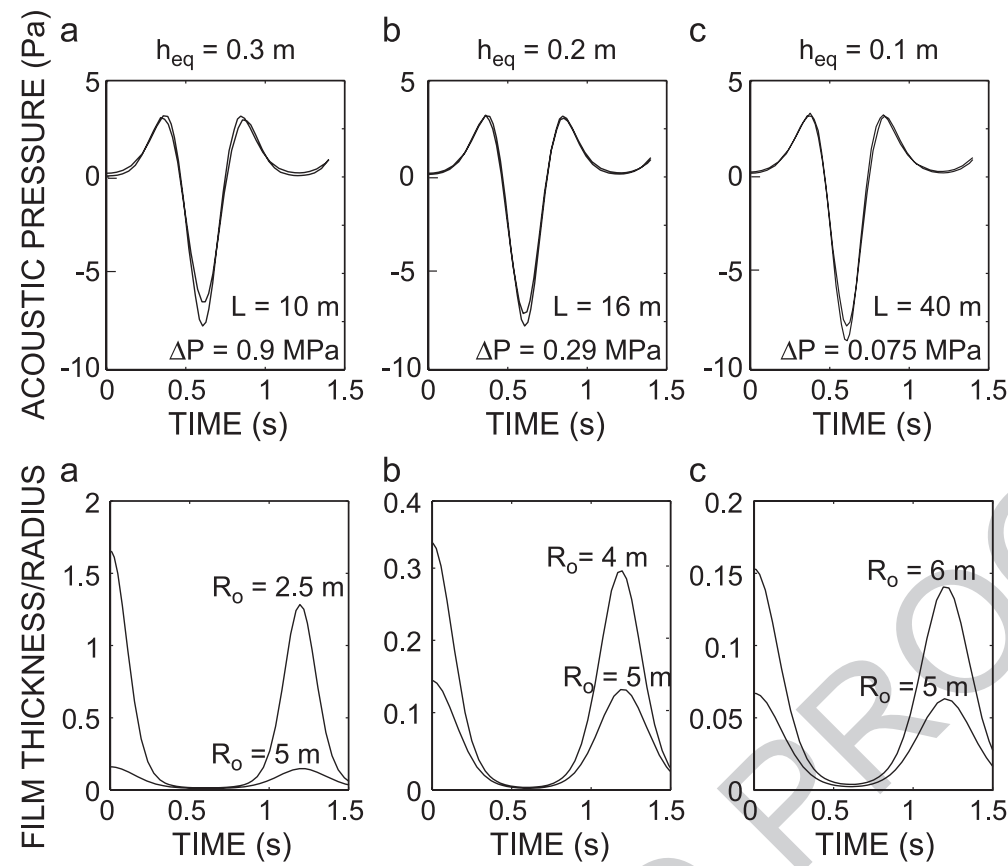

C

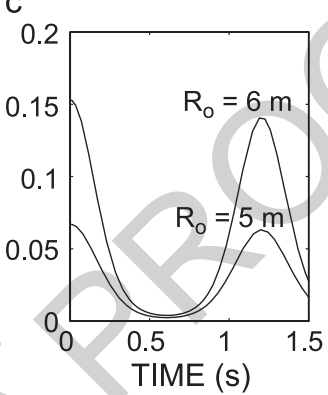

Fig. 9. Sensitivity analysis for various equilibrium thickness, $h_{\mathrm{eq}}=0.3 \mathrm{~m}$ for the right column, $h_{\mathrm{eq}}=0.2 \mathrm{~m}$ for the middle column, $h_{\mathrm{eq}}=0.1 \mathrm{~m}$ for the left column. Acoustic pressure is displayed on the top graphs and ratio between magma thickness and bubble radius $R_{0}$ on the bottom graphs. Note that the two graphs on the three top diagrams correspond to the cases shown in the graph below. The right column corresponds to bubble radius $R_{0}=2.5 \mathrm{~m}$, length $L=10 \mathrm{~m}$ and bubble overpressure $\Delta P=0.9 \mathrm{MPa}$. For the middle column, $R_{0}=4 \mathrm{~m}, L=16 \mathrm{~m}$ and $\Delta P=0.29 \mathrm{MPa}$. In the left column, $R_{0}=6 \mathrm{~m}, L=40 \mathrm{~m}$ and $\Delta P=0.075 \mathrm{MPa}$. Note that there is hardly any difference in acoustic pressure relative to reference case, $R_{0}=5 \mathrm{~m}, L=24 \mathrm{~m}$ and $\Delta P=0.15 \mathrm{MPa}, h_{\mathrm{eq}}=0.15 \mathrm{~m}$.

939 at Etna volcano, 1-5 m (Le Guern et al., 1982; Calvari 940 et al., 1994; Coltelli et al., 1998; Vergniolle, 2003) and 941 at Kilauea volcano ( $\approx 10 \mathrm{~m}$; Richter et al., 1970; Wolfe

et al., 1987) and is larger than that seen at Stromboli volcano $(\approx 1 \mathrm{~m}$; Chouet et al,, 1974). Thus, a conduit radius of $\approx 6 \mathrm{~m}$ seems reasonable for Shishaldin.

The conduit radius $R_{\mathrm{c}}$ can also be estimated from the initial bubble radius $R_{\mathrm{o}}$ and from the thickness $\delta$ of the magma present between the bubble and the solid wall, called the lateral film. If we assume that the thickness $\delta$ has reached its asymptotic value $\delta_{\infty}$, it can be calculated as (Batchelor, 1967)

$\delta_{\infty}=0.9 R_{\mathrm{c}}\left(\frac{\mu^{2}}{\rho_{\mathrm{liq}}^{2} R_{\mathrm{c}}^{3} g}\right)^{1 / 6}$.

For a magma viscosity of $500 \mathrm{~Pa} \mathrm{~s}$ and a bubble radius of $5 \mathrm{~m}$, the vertical film $\delta_{\infty}$ around each bubble is $\approx 0.86 \mathrm{~m}$ (Eq. (14)). Because the asymptotic value $\delta_{\infty}$ is seldom attained even for long bubbles (Fabre and Linné, 1992) and corresponds to a minimum value, the conduit radius can be safely estimated at $\approx 6 \mathrm{~m}$ from acoustic measurements.

We propose that the bubble radius is constant since we assume that the bubble volume fills the width of the tube and there is only one active vent at the summit (Fig. 5). The fairly well peaked frequency range during the whole of the eruption supports this assumption. If we suppose that the thickness of the magma above the bubble is constant and equal to $0.15 \mathrm{~m}$, the measured waveform can be matched by a bubble radius, length and overpressure of respectively $4 \mathrm{~m}, 27 \mathrm{~m}$ and 0.18 MPa or by a bubble with radius of a $6 \mathrm{~m}, 22 \mathrm{~m}$ and 0.13 MPa overpressure (Fig. 10). Enlarging the possible range of values for the initial bubble radius makes the radial oscillations of the bubble unlikely. When using these two extreme conditions for the bubble radius, the gas volume at atmospheric pressure is known with an accuracy better than $\pm 20 \%$. Therefore, a bubble
956 
a

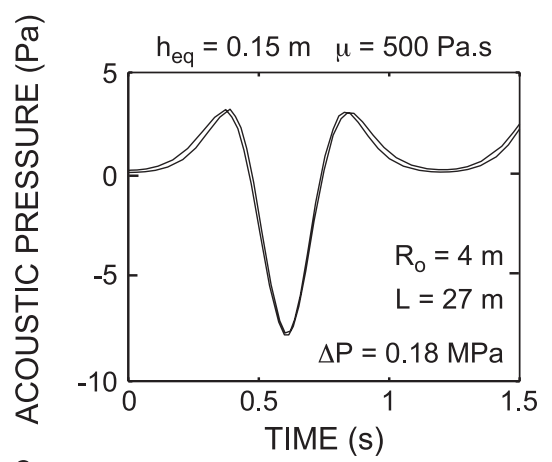

C

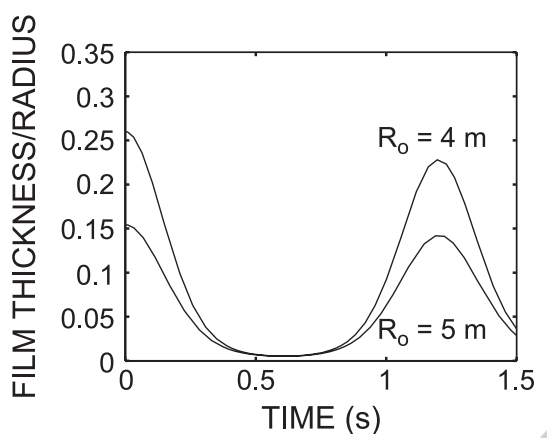

b

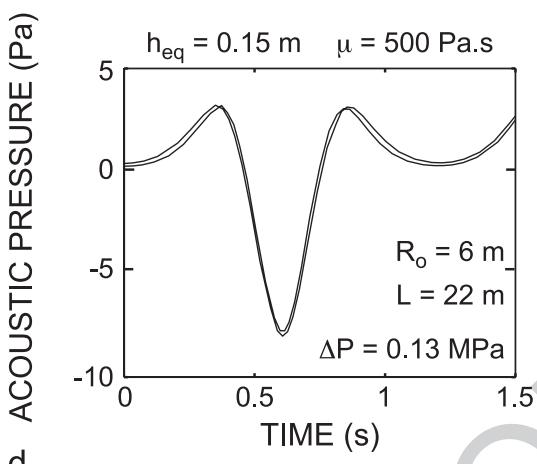

d
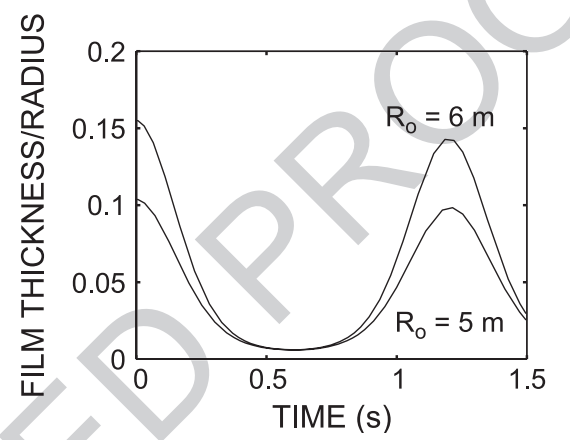

Fig. 10. Sensitivity analysis for various bubble radius $R_{0}=4 \mathrm{~m}$ for the right column, $R_{0}=6 \mathrm{~m}$ for the left column. Acoustic pressure is displayed on the top graphs and ratio between magma thickness and bubble radius $R_{0}$ on the bottom graphs. All the graphs corresponds to a constant equilibrium thickness, $h_{\mathrm{eq}}=0.15 \mathrm{~m}$ and a magma viscosity of $500 \mathrm{~Pa}$. The right column corresponds to bubble length $L=27 \mathrm{~m}$ and bubble overpressure $\Delta P=0.18 \mathrm{MPa}$. In the left column, $L=22 \mathrm{~m}$ and $\Delta P=0.13 \mathrm{MPa}$. Note that there is hardly any difference in acoustic pressure relative to the reference case, $R_{0}=5 \mathrm{~m}, L=24 \mathrm{~m}$ and $\Delta P=0.15 \mathrm{MPa}, h_{\mathrm{eq}}=0.15 \mathrm{~m}$.

976 radius of $5 \mathrm{~m}$ generates the best synthetic waveforms

977 regardless of when the signal is chosen during the two

978 Strombolian phases. The uncertainties on the bubble

979 radius are probably around $1 \mathrm{~m}$ at most if we suppose

980 that the thickness $h_{\mathrm{eq}}$ of magma above the bubble is

981 properly determined.

982

983

984

985

986

987

988

989

990

991

992

\subsection{Constraints on bubble length}

When a long bubble breaks, such as during a Strombolian explosion, the duration of gas expulsion depends on the gas velocity and the bubble length. If the gas is expelled at a velocity deduced from height measurements $(\approx 50 \mathrm{~m} / \mathrm{s})$, a $100-\mathrm{m}$ long bubble could produce sound for $2 \mathrm{~s}$, which could be measured on acoustic records. However, the sound produced by a steady gas jet carrying solid fragments is a dipolar source, which radiates sound with less efficiency than a monopole source such as a Strombolian explosion (Woulff and McGetchin, 1976). It is even worse in term of sound radiation if the sound is produced by a gas phase free of solid fragments, a quadrupole source resulting of turbulence in the gas jet itself. Measurements of acoustic pressure, recorded at $6.5 \mathrm{~km}$ from the vent and with potentially some wind, do not show any sign of an signal induced by the gas jet itself. Therefore, no constraint can be provided on bubble length.

\section{Main results}

\subsection{Bubble length and overpressure}

It is now possible to look at the evolution of bubble characteristics during the two Strombolian phases to constrain the dynamics of the eruption.
1002

1003

1004

993

994

995

996

997

998

999

1000

1001

1005

1006

1007 
1008 The first Strombolian phase (April 19, 1999), which 1009 occurs almost immediately after the Subplinian phase, 1010 displays no noticeable time evolution in bubble length 1011 or overpressure (Fig. 11). Although the bubbles are 1012 long $(82 \pm 11 \mathrm{~m})$, their lengths are less than 20 times 1013 the bubble radius, as is expected for slug flow (Wallis, 1014 1969). Bubble overpressures are relatively small, 1015 around $0.083 \pm 0.03 \mathrm{MPa}$. The end of this phase is 1016 difficult to see because acoustic signals decrease slowly 1017 before falling below the noise level.

1018 The second Strombolian phase (22nd and 23rd of 1019 April 1999; Fig. 12) shows more variation than the first 1020 (Fig. 11). Bubble lengths, between 10 and $60 \mathrm{~m}$, are still 1021 less than 20 times the bubble radius. Bubble overpres1022 sure during the second Strombolian phase (Fig. 12) 1023 starts and stays at a relatively low value $(0.15 \mathrm{MPa})$, for 1024 the first $17 \mathrm{~h}$. It presents a peak at $1.4 \mathrm{MPa}$ on the $23 \mathrm{rd}$ 1025 of April between 04:40 and 10:13 h, although there is 1026 no associated change in the number of events.
While none of these explosions was visually observed, tremor amplitude at the time of the pressure peak on April 23 was the strongest ever recorded by AVO (Thompson et al., 2002). Although no visual observations were made of the Strombolian explosions, satellite imagery at 05:30 $\mathrm{h}$ shows a small ash plume, and video taken of the Shishaldin vent at 21:30 $\mathrm{h}$ shows the development of another small plume. These can be either the combined effects of frequently breaking, very long, overpressurised bubbles, as shown by the increase in surface flux $\approx 6000 \mathrm{~m}^{3} / \mathrm{s}$ (Fig. 15) or proper ash plumes, as shown developing during the pre-Subplinian and the Subplinian phases (Vergniolle and Caplan-Auerbach, 2003b,c, submitted 3 and 4).

Here, we propose that the peak in overpressure corresponds to large Strombolian bubbles rising through a gas-rich magma. Laboratory experiments show that under different conditions in the reservoir, a
1027

1028

1029

1030

1031

1032

1033

1034

1035

1036

1037

1038

1039

1040

1041

1042

1043

1044

1045

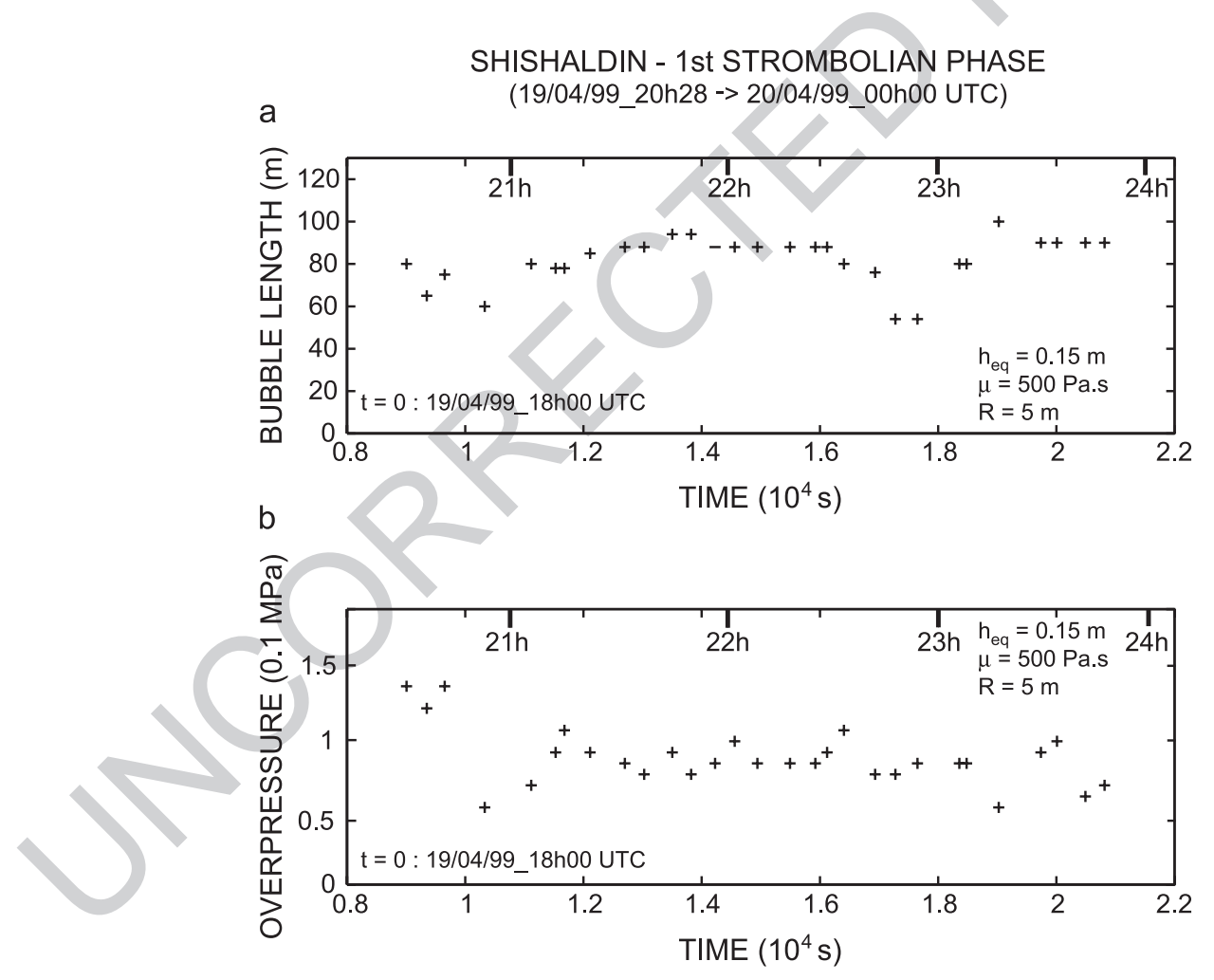

Fig. 11. Results of synthetic waveforms on the largest explosion per $400 \mathrm{~s}$ during the first Strombolian phase of the 19th of April 1999. Bubble radius $R_{0}$ is $5 \mathrm{~m}$, magma thickness above bubble $h_{\mathrm{eq}}$ is $0.15 \mathrm{~m}$ and magma viscosity $\mu$ is $500 \mathrm{~Pa}$. Time $t=0$ is 18:00 h on 19/04/1999 (UTC). (a) Bubble length at the surface $(\mathrm{m})$. (b) Bubble overpressure at the surface $(\times 0.1 \mathrm{MPa})$. 

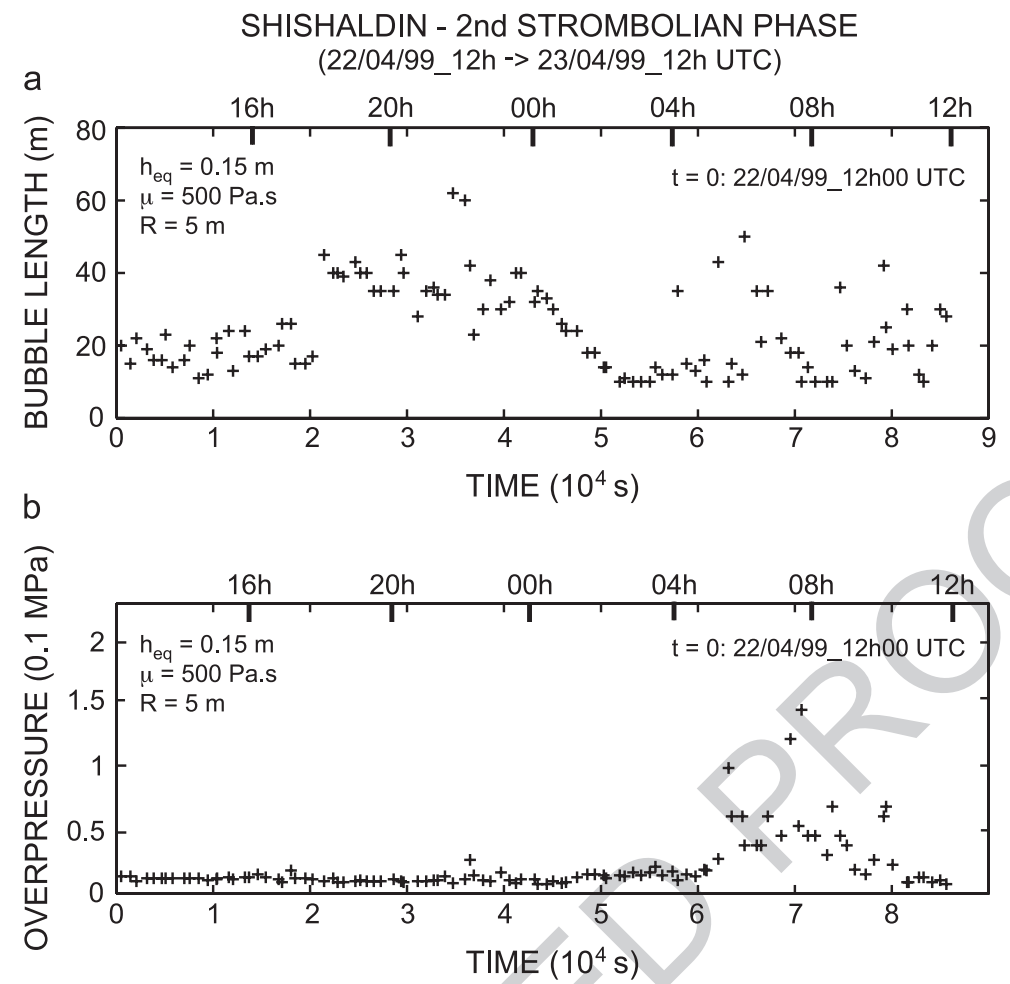

Fig. 12. Results of synthetic waveforms on the largest explosion per $800 \mathrm{~s}$ during the second Strombolian phase of the 22nd and 23rd of April 1999. Bubble radius $R_{0}$ is $5 \mathrm{~m}$, magma thickness above bubble $h_{\mathrm{eq}}$ is $0.15 \mathrm{~m}$ and magma viscosity $\mu$ is $500 \mathrm{~Pa}$. Time $t=0$ is $12: 00 \mathrm{~h}$ on $22 / 04 /$ 1999 (UTC). (a) Bubble length at the surface (m). (b) Bubble overpressure at the surface $(\times 0.1 \mathrm{MPa})$.

1046 variable quantity of small bubbles is released in the 1047 conduit (Fig. 13), which depends on the foam dynam1048 ics at the top of the reservoir and its lateral spreading. 1049 When the latter is relatively strong, the liquid in the 1050 tube is very rich in small bubbles, which rise as an 1051 annular curtain of small bubbles (Fig. 13c).

1052 The consequence is that the apparent viscosity of a 1053 bubbly magma is much greater than the viscosity of a 1054 magma without bubbles (Jaupart and Vergniolle, 1055 1989). Since the large bubbles of the Strombolian 1056 phase come from the depth of the reservoir and are 1057 formed with an initial overpressure, their final over1058 pressure at the surface strongly depends on the vis1059 cosity of the mixture in which they are rising 1060 (Vergniolle, 1998).

1061 The average bubble length, during the second 1062 Strombolian phase $(24 \pm 12 \mathrm{~m})$ is less than a third 1063 of the length estimated for the first Strombolian 1064 phase. The bubble overpressure during the first 17 $1065 \mathrm{~h}$ of the second one (Fig. 12) is twice that recorded during the first Strombolian phase (Fig. 11). These differences in bubble lengths and bubble overpressures support the interpretation that the first Strombolian phase results from a strong decompression induced by the Subplinian phase (Vergniolle and Caplan-Auerbach, 2003c,d, submitted 4 and 5) whereas the second one is more typical of a classical basaltic eruption with relatively small $(0.15 \mathrm{MPa})$ overpressure. The peak in overpressure is probably the consequence of a magma in the conduit richer in small gas bubbles as shown in the laboratory experiments (Fig. 13c).

\subsection{Gas volume and gas flux}

Given bubble radius, length and overpressure during the two Strombolian phases, it is fairly easy to calculate the gas volume and gas flux emitted at the surface per bubble. Gas volume and gas flux, calculated at atmospheric pressure, are fairly constant
1066 1067 1068 1069 1070 1071 1072 1073 1074 1075 1076 1077 1078 1079

1080 1081 1082 1083 1084 


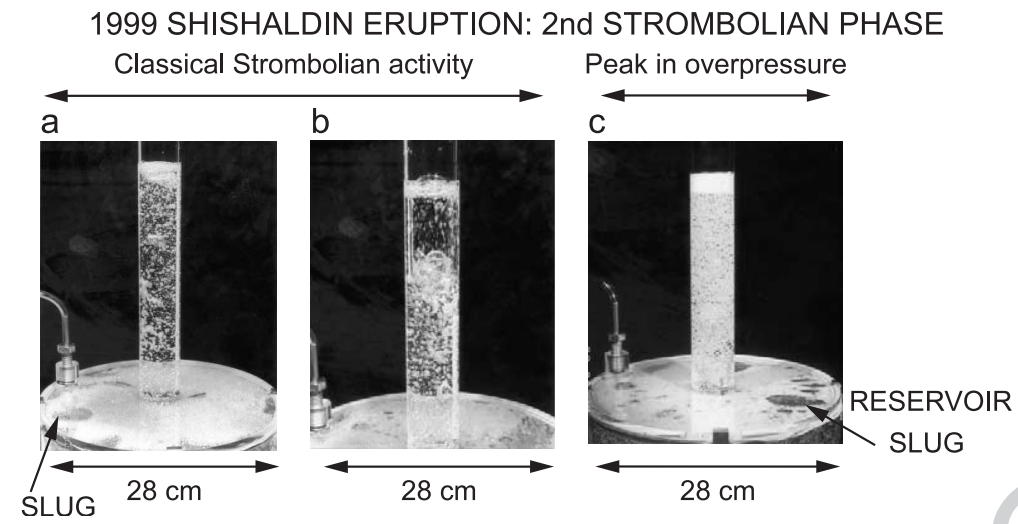

Fig. 13. Laboratory experiments showing that the conduit can contain a small gas volume fraction $(a, b)$ or a relatively large gas volume fraction with a small foam lying on the top of the liquid (c). Liquid is a silicone oil (Rhodorsil) of viscosity $0.1 \mathrm{~Pa} \mathrm{~s}$ (a, b) and $0.01 \mathrm{~Pa} \mathrm{~s}$ (c) for a gas flux of $3.0 \times 10^{-5} \mathrm{~m}^{3} / \mathrm{s}(\mathrm{a}, \mathrm{b})$ and $1.3 \times 10^{-5} \mathrm{~m}^{3} / \mathrm{s}$. The conduit diameter is $4.4 \mathrm{~cm}$ and the number of bubbles at the base of the reservoir is 185 . (a) Foam at the top of the reservoir (white part) has started to coalesce (black part on the left-hand side) to produce a slug, i.e. a large gas bubble. (b) Large gas bubble in the conduit, similar to classical Strombolian explosions. (c) Foam at the top of the reservoir (white part) has started to coalesce (black part on the right-hand side) and is about to produce a large bubble, which then will migrate in a conduit rich in small bubbles. Note that there is a permanent foam layer staying at the top of the liquid. This is the laboratory equivalent of the second Strombolian phase during its peak in overpressure.

1085 during the first Strombolian phase and are respective1086 ly $1.3 \times 10^{4} \pm 0.2 \times 10^{4}$ and $2.9 \times 10^{3} \pm 4.1 \times 10^{2}$ $1087 \mathrm{~m}^{3} / \mathrm{s}$ (Figs. 14 and 15 ).

1088 For the second Strombolian phase, we observe a 1089 peak between $04: 40$ and 10:13 h UT $\left(\approx 1.4 \times 10^{4} \mathrm{~m}^{3}\right.$ 1090 for gas volume ejected per bubble and $\approx 3.8 \times 10^{3} \mathrm{~m}^{3}$, $1091 \mathrm{~s}$ for the gas flux) following a 17 -h quiet period at $10924.7 \times 10^{3} \pm 1.9 \times 10^{3}$ and $1.0 \times 10^{3} \pm 4.7 \times 10^{2} \mathrm{~m}^{3} / \mathrm{s}$ 1093 (Fig. 15). Gas volume and gas flux average for the 1094 whole second Strombolian phase is $0.9 \times 10^{4} \pm$ $10950.8 \times 10^{4}$ and $2.2 \times 10^{3} \pm 1.6 \times 10^{3} \mathrm{~m}^{3} / \mathrm{s}$. If we as1096 sume that $\mathrm{CO}_{2}$ is the major component of the gas, the 1097 mass flux is equal to $1.2 \times 10^{3}$ and $8.7 \times 10^{2} \mathrm{~kg} / \mathrm{s}$ for 1098 the first and the second Strombolian phases. Mass flux 1099 has a minimum value of 470 and $360 \mathrm{~kg} / \mathrm{s}$ in the 1100 endmember case of a pure $\mathrm{H}_{2} \mathrm{O}$ phase.

1101 The total gas volume is estimated by counting the 1102 number of explosions per $400 \mathrm{~s}$ for the first Strombo1103 lian phase and per $800 \mathrm{~s}$ for the second Strombolian 1104 phase. On average one explosion occurs each $8.7 \mathrm{~s}$ for 1105 the first Strombolian phase and each $12 \mathrm{~s}$ for the 1106 second one (Caplan-Auerbach and McNutt, 2003). 1107 The total gas volume ejected at atmospheric pressure 1108 is $3.3 \times 10^{7} \mathrm{~m}^{3}$ for the first Strombolian phase and $11091.0 \times 10^{8} \mathrm{~m}^{3}$ for the second. We have seen before that 1110 although there are a few simplifying assumptions, the 1111 determination of gas volume, and hence gas flux is known with an accuracy of $\pm 20 \%$ in the framework proposed by the model of bubble vibration.

The number of bubbles has been estimated by counting any bubble with acoustic pressure above the detection limit $(\approx 0.5 \mathrm{~Pa})$. The total gas volume and gas flux given above, were estimated using the volume of the largest bubble and the number of events above the detection threshold. The total volume of the smallest detectable bubbles released at atmospheric pressure is $\approx 1.1 \times 10^{7}$ and $\approx 5.0 \times 10^{7} \mathrm{~m}^{3}$ during the first and second Strombolian phase. If the distribution of gas volumes follows a gaussian law, the average gas volume is the mean between the minimum and the maximum gas volume, $\approx 2.3 \times 10^{7}$ and $\approx 7.7 \times 10^{7} \mathrm{~m}^{3}$ for the first and second Strombolian phase. Gas flux based on that method are reduced by a factor of 0.67 and 0.74 during the first and second Strombolian phases.

Note that the sensitivity, used in this paper, for the pressure sensor is the theoretical value, $0.36 \mathrm{mV} / \mathrm{Pa}$. If instead we use the uncalibrated value of $0.2 \mathrm{mV} / \mathrm{Pa}$, the data amplitudes are multiplied by 0.56 . Because the frequency of the signal is not affected by the calibration, the bubbles have the same characteristics in size but gas overpressure increases by 1.8. This leads to a maximum in overpressure of $2.5 \mathrm{MPa}$ for a mean around $0.14 \mathrm{MPa}$ during the second Strombolian phase. 


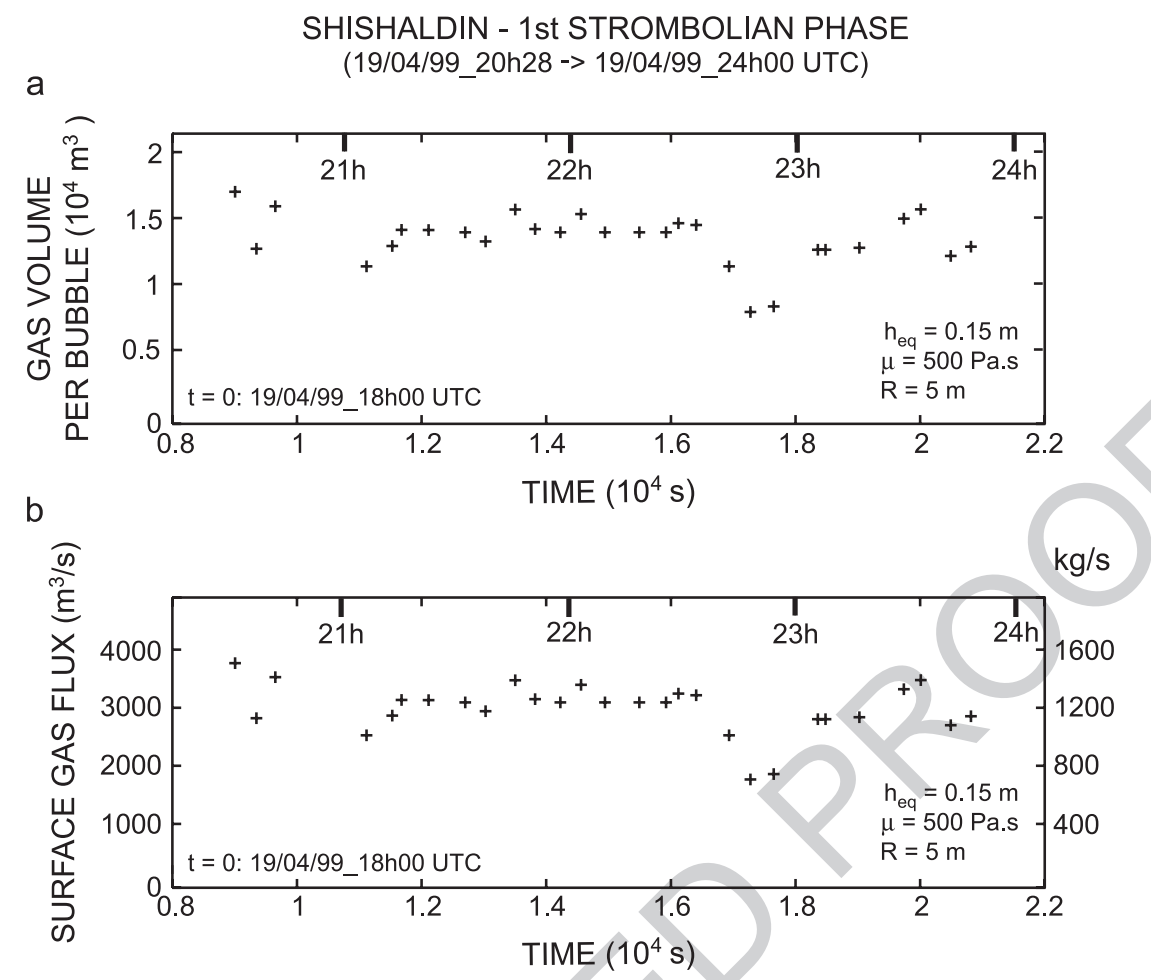

Fig. 14. Bubble radius $R_{0}$ is $5 \mathrm{~m}$, magma thickness above bubble $h_{\mathrm{eq}}$ is $0.15 \mathrm{~m}$ and magma viscosity $\mu$ is $500 \mathrm{~Pa}$. Time $t=0$ is $18: 00 \mathrm{~h}$ the $19 /$ 04/1999 (UTC). First Strombolian phase: (a) gas volume ejected by the largest explosion every $400 \mathrm{~s}$ and calculated at atmospheric pressure $\left(\mathrm{m}^{3}\right.$ $\left.\mathrm{s}^{-1}\right)$ and as mass flux $(\mathrm{kg} / \mathrm{s})$ assuming a pure $\mathrm{CO}_{2}$ phase.

1139 Gas volume and gas flux at the surface increase by less 1140 than $20 \%$. Therefore, the results present in this paper 1141 are fairly robust, except for the gas overpressure during 1142 Strombolian explosions, and do not rely heavily on the 1143 exact value of the sensitivity.

\section{7. Gas velocity from acoustic power}

1145 Thus far we have discussed a model for acoustic 1146 measurements based on synthetic waveforms. How1147 ever, there might be cases where the quality of 1148 acoustic measurements or the intrinsic character of 1149 the signal, prevent us from producing synthetic wave1150 forms. We propose a new method, which overcomes 1151 that difficulty and allows estimates of gas velocity. We 1152 can then compare these results with the results 1153 obtained from synthetic waveforms to validate a 1154 simple and robust method to obtain gas velocity and 1155 gas volume at the vent.
Eq. (6), which describes the time evolution of bubble radius, is required to calculate gas velocity from synthetic waveforms. The maximum velocity of the magma layer above the bubble is found to be $\approx 30 \mathrm{~m} / \mathrm{s}$ for the first $17 \mathrm{~h}$ and can reach up to $70 \mathrm{~m} / \mathrm{s}$ during the final 4-h climax (Fig. 16). This velocity is that of the magma layer and can be smaller than the gas velocity once the bubble has broken. Visual observations by pilots show that ejecta reached heights of a few hundreds of meters earlier on the same day (Nye et al., 2002). If velocity $v$ is simply related to height $H$ by $v=\sqrt{2 g H}$ (Wilson, 1980; Sparks et al., 1997), ejecta velocity is between 45 and70 m/s. Although visual observations were not made at exactly the time during which the pressure sensor recorded Strombolian explosions, there is an order-of-magnitude agreement between explosion waveforms and observed ejecta.

Woulff and McGetchin (1976) have suggested that acoustic power could be used to estimate gas velocity
1156 
SHISHALDIN - 2nd STROMBOLIAN PHASE

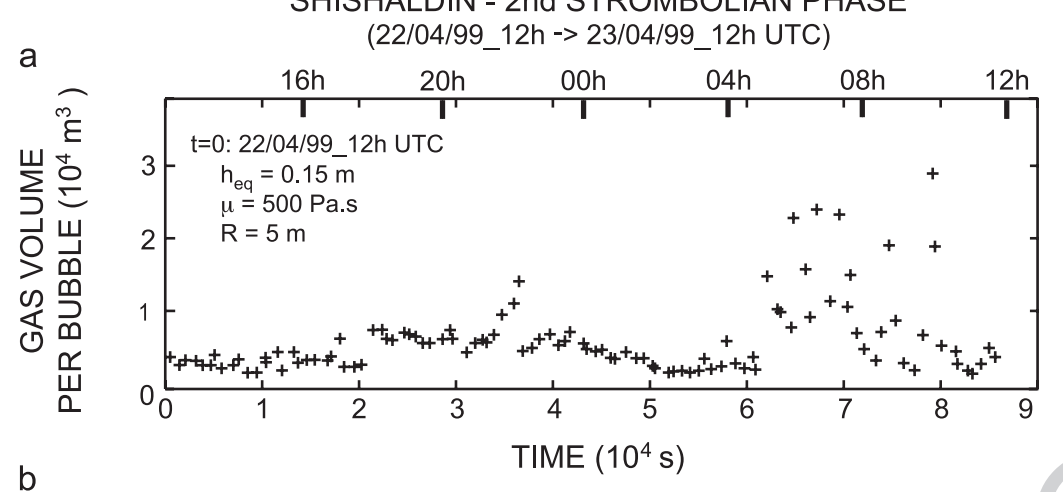

b

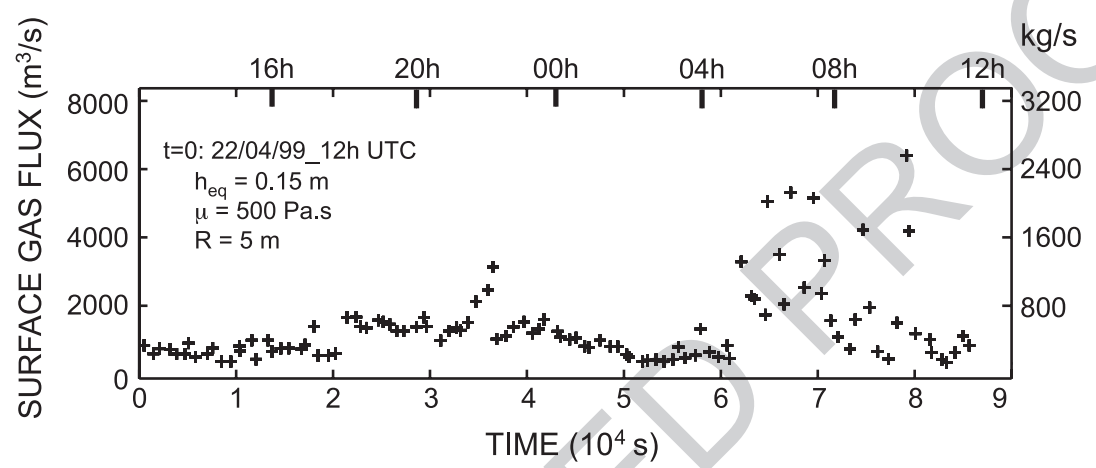

Fig. 15. Bubble radius $R_{0}$ is $5 \mathrm{~m}$, magma thickness above bubble $h_{\mathrm{eq}}$ is $0.15 \mathrm{~m}$ and magma viscosity $\mu$ is $500 \mathrm{~Pa}$. Time $t=0$ is $12: 00 \mathrm{~h}$ the $22 /$ $04 / 1999$ explosion every $400 \mathrm{~s}$ and calculated at atmospheric pressure $\left(\mathrm{m}^{3}\right)$. (b) Gas flux ejected by the largest explosion every $400 \mathrm{~s}$ and calculated at atmospheric pressure $\left(\mathrm{m}^{3} \mathrm{~s}^{-1}\right)$ and as a mass flux $(\mathrm{kg} / \mathrm{s})$ assuming a pure $\mathrm{CO}_{2}$ phase.

1176 during volcanic eruptions. The total acoustic power, in 1177 Watts, emitted in a half sphere of radius equal to the 1178 distance $r$ between the vents and the microphone, here $11796.5 \mathrm{~km}$, and radiated during a time interval $T$, is equal 1180 to

$$
\Pi=\frac{\pi r^{2}}{\rho_{\text {air }} c T} \int_{0}^{T}\left|p_{\text {ac }}-p_{\text {air }}\right|^{2} \mathrm{~d} t
$$

1181 where $\rho_{\text {air }}=0.9 \mathrm{~kg} \cdot \mathrm{m}^{-3}$ at $2850 \mathrm{~m}$ elevation (Batch1183 elor, 1967) and $c=340 \mathrm{~m} / \mathrm{s}$ is the sound speed (Light1184 hill, 1978). Acoustic power can be then easily 1185 measured from acoustic records. However, the rela1186 tionship between acoustic power and gas velocity 1187 depends strongly on the source of sound, which can 1188 be monopole, dipole or quadrupole. A monopole 1189 source, which radiates isotropically, corresponds to a 1190 varying mass flux without external forces or varying 1191 stress. For a dipole source, there is a solid boundary 1192 which provides an external force. For a quadrupole source, there is a varying momentum flux which acts on the flow. In each case, it is possible to calculate acoustic power by assuming that the signal is periodic and monochromatic with a radian frequency $\omega$ and potentially add the contribution of every frequency in a simple linear way.

The source of volcanic explosions has been shown to be a monopole (Vergniolle and Brandeis, 1994). For a monopole source, the excess pressure depends on the rate of mass outflow from the source, $\dot{\mathrm{q}}$ in equation (see Eq. (1)). If we assume monochromatic oscillations of frequency $\omega$, $\dot{\mathrm{q}}$ has the same dimension as $\omega q$. The two are strictly equivalent if oscillations are small. This simplification gives an order of magnitude for acoustic power. Temkin (1981) uses the notation $S_{\omega}$ for the volume flux instead of the mass flux $q=\rho_{\text {air }} S_{\omega}$ used by Lighthill (1978). For a spherical source of radius $R_{\mathrm{b}}$,

$S_{\omega}=4 \pi R_{\mathrm{b}}^{2} U$ 


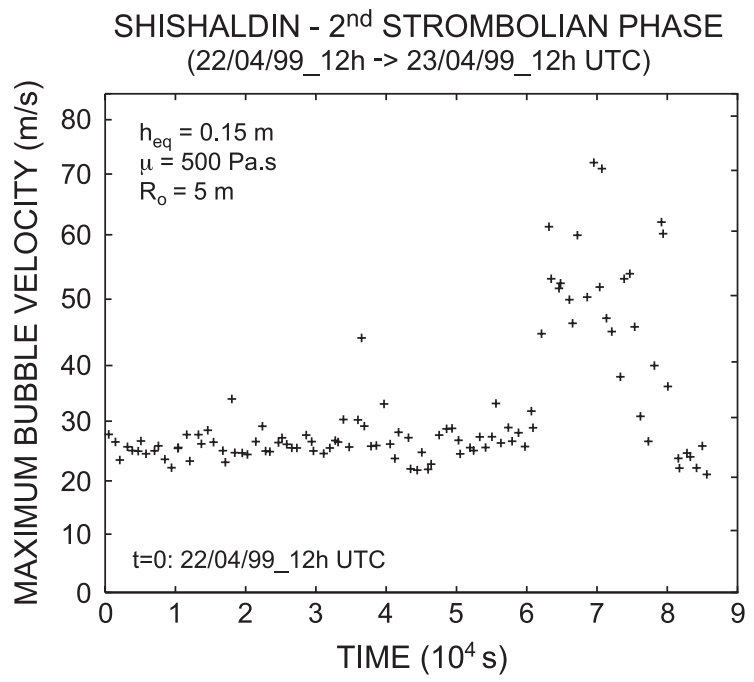

Fig. 16. Maximum magma velocity $(\mathrm{m} / \mathrm{s})$ for each largest bubble per $800 \mathrm{~s}$ during the second Strombolian phase and estimated from modelling the bubble vibration. Bubble radius $R_{0}$ is $5 \mathrm{~m}$, magma thickness above bubble $h_{\text {eq }}$ is $0.15 \mathrm{~m}$ and magma viscosity $\mu$ is 500 Pas. Time $t=0$ is $12: 00 \mathrm{~h}$ on $22 / 04 / 1999$ (UTC).

1212 where $U$ is the radial velocity. The coefficient 4 is to 1213 be suppressed for a circular vent radiating acoustic 1214 pressure by ejecting vertical gas at a varying velocity $1215 U$. By assuming small monochromatic oscillations at frequency $\omega$, acoustic power $\Pi_{m}$ radiated in an infinite space is

1216

1217

$\Pi_{m}=\frac{\rho_{\mathrm{air}} \omega^{2} S_{\omega}^{2}}{4 \pi c}$

where $\rho_{\text {air }}$ is the air density and $c$ the sound speed in air (Temkin, 1981). The radiation of half a bubble in half a space is equivalent to that of a spherical bubble in infinite space (see Eq. (1)). Therefore, $\Pi_{m}$ (see Eq. (17)) corresponds to the acoustic radiation produced by each Strombolian explosion at Shishaldin volcano.

For small monochromatic oscillations at frequency $\omega$, the oscillatory velocity $U$ has the same dimension as $\omega R_{\mathrm{b}}$ (Landau and Lifshitz, 1987). Using this approximate value of $\omega$ in Eq. (17), acoustic power depends mainly on gas velocity $U$

$\Pi_{m}=K_{m} \frac{4 \pi R_{\mathrm{b}}^{2} \rho_{\mathrm{air}} U^{4}}{c}$

where $K_{m}$ is an empirical constant. We have just shown that $K_{m}=1$ represents the exact solution for a spherical source and $K_{m}=1 / 16$ is the value to be used for a circular flat orifice (Vergniolle and CaplanAuerbach, 2003a, this issue). Our formulation (Eq. (18)) is equivalent to equations used by Woulff and McGetchin (1976), but adds an exact value for $K_{m}$.
1218

1220

1221

1222

1223

1224

1225

1226

1227

1228

1229

1230

1232

1233

1234

1235

1236

1237
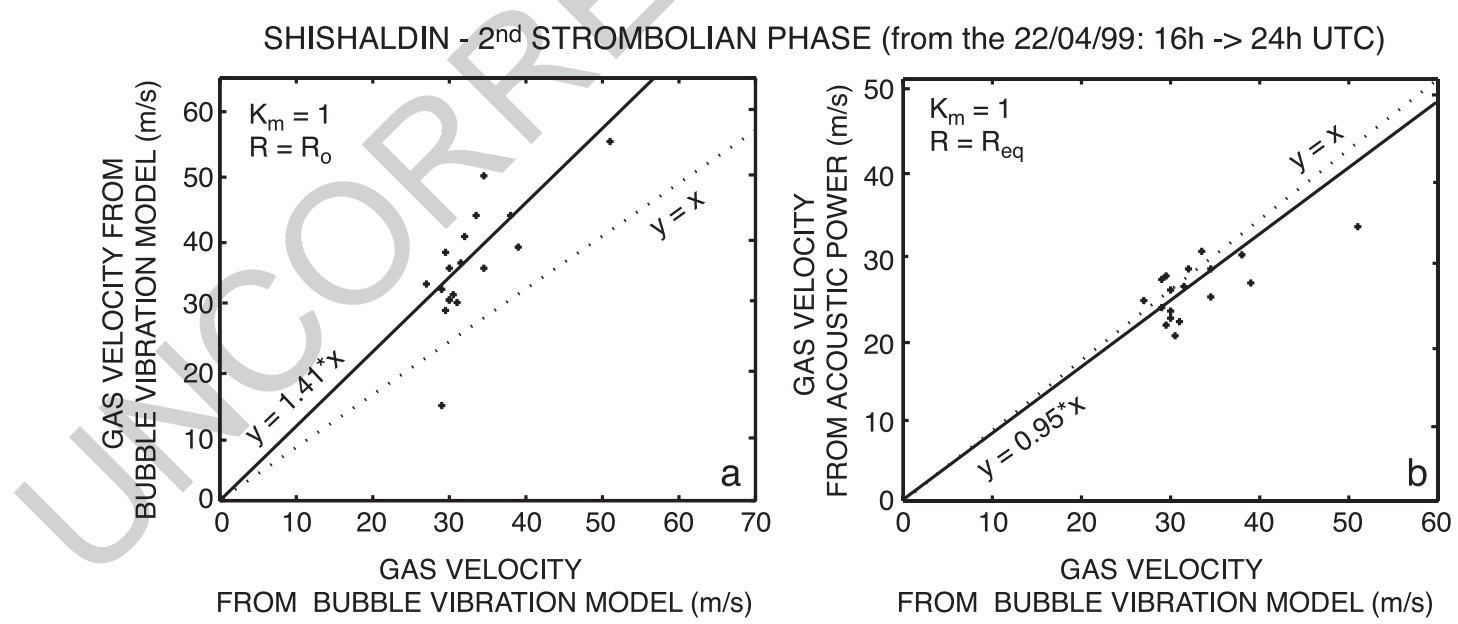

FROM BUBBLE VIBRATION MODEL $(\mathrm{m} / \mathrm{s})$

Fig. 17. Comparison between two methods of estimating velocities during the second Strombolian phase (from 16:00 to 24:00 h, the 22nd of April 1999). On $x$-axis, velocity is calculated by the full modelling of bubble vibration (Eq. (6)). On $y$-axis, velocity is calculated from acoustic power (Eq. (18)) using (a) the initial bubble radius $R_{0}$ and (b) the equilibrium radius $R_{\text {eq. }}$. 
1238 Note that in all the above analysis the length scale 1239 is assumed to be the bubble radius. In theory, it should 1240 be taken as the equilibrium radius $R_{e q}$ (see Eq. (5)). 1241 However, in practice, $R_{\text {eq }}$ is unknown but can be 1242 estimated by the minimum bubble radius $R_{0}$, which 1243 is on the order of the conduit radius. For small 1244 oscillations, the two length scales are the same but 1245 for mild or strong oscillations, there is a correcting 1246 factor in Eq. (18), which accounts for the amplitude of 1247 the oscillation. For simplicity, we estimate gas veloc1248 ity using the initial bubble radius.

1249 At Shishaldin, gas velocities are calculated from 1250 averaging acoustic power over $1.5 \mathrm{~s}$ and using a 1251 constant $K_{m}$ of 1 (Eq. (18)). Gas velocities estimated 1252 from acoustic power are slightly larger (between 30 1253 and $70 \mathrm{~m} / \mathrm{s}$ ) than values estimated by the full model of 1254 bubble vibration (between 30 and $50 \mathrm{~m} / \mathrm{s}$ ) (Fig. 17). 1255 The relationship between both estimates is roughly 1256 linear with a slope of 1.4 (Fig. 17a). The spreading of 1257 the correlation is related to the degree of non-linearity 1258 in bubble oscillation, which is always mild. Estimates 1259 of velocity from the exact solution of motion during 1260 bubble vibration or from acoustic power are exactly 1261 the same if using the equilibrium radius (Fig. 17b). 1262 Note that velocities have only been estimated for 1263 bubble vibration. This calculation ignores possible 1264 accelerations effects due to the motion of hot mag1265 matic gas once the bubble has burst. At Stromboli, 1266 velocities obtained from modelling of bubble vibra1267 tion are also smaller than independent estimates of gas 1268 velocity above the vent (Weill et al., 1992; Vergniolle 1269 and Brandeis, 1996). Therefore, although the acoustic 1270 power method overestimates velocities during bubble 1271 vibration if using the initial bubble radius, gas veloc1272 ity, once the bubble has burst, is probably safely 1273 estimated by using acoustic power with a constant $1274 K_{m}$ of 1 .

\section{8. Comparison with other volcanoes and 1276 conclusion}

1277 The occurrence, at Shishaldin, of bubbles whose 1278 length is significantly longer than the radius is similar 1279 to Stromboli, whose bubbles have lengths between 1 1280 and $25 \mathrm{~m}$ for a bubble radius of $1 \mathrm{~m}$ (Vergniolle and 1281 Brandeis, 1996), and to Etna volcano, with bubble 1282 length between 5 and $40 \mathrm{~m}$ for a bubble radius of $5 \mathrm{~m}$
(Vergniolle, 2003). This is the trademark of a welldeveloped slug flow (Wallis, 1969). Therefore, bubbles present during the two Strombolian phases of Shishaldin are not long enough to represent an inner gas jet, such as that produced during fire fountains. Because no confirmed fire fountaining episodes were observed at Shishaldin, we feel that this estimate is robust.

Pressure could be used as a very good variable to estimate the "strength" of an eruption. Although very few measurements exist, there is a trend between large overpressure and explosivity. Bubble overpressures have been estimated at $\approx 0.10 \mathrm{MPa}$ at Stromboli (Vergniolle and Brandeis, 1996) and between 0.05 $\mathrm{MPa}$ and 0.6 MPa at Etna (Vergniolle, 2003). Although bubble overpressure at Shishaldin can be very strong, our estimates are still on the same order of magnitude as other strong Strombolian eruptions, such as one recorded at Sakurajima volcano (Japan), 0.2-5 MPa (Morrissey and Chouet, 1997b). Furthermore, bubble overpressure at Shishaldin is always much smaller than estimates from explosive eruptions, such as Mount Tokachi (Japan) in 1988 (between 0.1 and $1 \mathrm{MPa}$ ), Mount Ruapehu (New Zealand, between 0.2 and $5 \mathrm{MPa}$ ), the $1975 \mathrm{Ngauruhoe}$ eruption (New Zealand, between 5 and $6 \mathrm{MPa}$ ), and Mount Pinatubo (Philippines) in 1991 ( $\geq 5 \mathrm{MPa}$ ) (Morrissey and Chouet, 1997b). The initial overpressure at the start of the Mount Saint Helens eruption has been estimated at 7.5 MPa (Kieffer, 1981).

We next compare gas volume at Shishaldin to other basaltic eruptions. At Shishaldin, the gas volume ejected per bubble, $\approx 1.3 \times 10^{4}$ and $\approx 1.0 \times 10^{4} \mathrm{~m}^{3}$ for the first and second Strombolian phases respectively, is larger than that observed at Stromboli, between 2 and $200 \mathrm{~m}^{3}$ when measured using acoustic data (Vergniolle and Brandeis, 1996) and between 40 and $180 \mathrm{~m}^{3}$ for one second from COSPEC measurements (Allard et al., 1994). Allard et al. (1994) further note that most degassing at Stromboli occurs passively, rather than during explosions, and this may also be true for Shishaldin, as a gas plume is a constant presence at the summit. At Shishaldin, gas flux ejected at atmospheric pressure, probably mainly $\mathrm{CO}_{2}, \mathrm{H}_{2} \mathrm{O}$ and $\mathrm{SO}_{2}$, is $\approx 3.0 \times 10^{3} \mathrm{~m}^{3} / \mathrm{s}$ for the two Strombolian phases. COSPEC measurements, over the main summit craters area at Etna volcano, shows that the gas flux of $\mathrm{SO}_{2}$ is $22,2.2 \times 10^{3}$ and $4.4 \times 10^{3} \mathrm{~m}^{3} / \mathrm{s}$ for the main three 
1331 kinds of activity at Etna volcano, namely low passive 1332 fuming, high Strombolian activity and lava fountains 1333 paroxysm (Allard, 1997). Gas volumes expelled per 1334 bubble at Shishaldin volcano is also larger than what is 1335 estimated from acoustic measurements at Etna volcano, $13364.7 \times 10^{3} \pm 1.7 \times 10^{3} \mathrm{~m}^{3}$ (Vergniolle, 2003). The total 1337 gas volume ejected per eruptive episode during the 13382001 eruption of Etna volcano is $\approx 6.2 \times 10^{6} \mathrm{~m}^{3}$ for a 1339 duration of $4 \mathrm{~h}$, much less than at Shishaldin volcano, $13403.3 \times 10^{7} \mathrm{~m}^{3}$ for the first Strombolian phase and $13411.0 \times 10^{8} \mathrm{~m}^{3}$ for the second one. Fire fountains at 1342 Kilauea volcano correspond to a gas volume at atmo1343 spheric pressure between $5.0 \times 10^{8}$ and $3.0 \times 10^{9} \mathrm{~m}^{3}$ 1344 for the Pu'u O'o eruption (Vergniolle and Jaupart, 1345 1990), which is more than 20 times that of Shishaldin. 1346 Therefore, the large difference in gas volumes is 1347 representative of two different eruption dynamics, such 1348 as an inner gas jet feeding a fire fountain at a volcano 1349 such as Kilauea or a continuous series of large bubbles 1350 like at Shishaldin volcano.

1351 Although Shishaldin volcano is difficult to access, 1352 acoustic data have proved to be very valuable in 1353 quantifying its eruption dynamics. Bubble lengths 1354 and overpressure at the surface can be estimated from 1355 synthetic waveforms, as well as gas velocity during 1356 each Strombolian explosion. Acoustic pressure, which 1357 can be easily measured close to an active volcano, 1358 allows us to estimate physical variables, such as 1359 pressure and velocity needed for understanding the 1360 eruptive behaviour.

\section{9. Uncited references}

1362 Arciniega-Ceballos et al., 1999

1363 Bikerman, 1973

1364 Chouet, 1996

1365 Cruz and Chouet, 1997

1366 Eichelberger et al., 1986

1367 Garcès, 1997

1368 Garcès, 2000

1369 Garcès and Hansen, 1998

1370 Ishihara, 1985

1371 Johnson, 2003

1372 McNutt, 2000

1373 Morrissey and Chouet, 1997a

1374 Neuberg et al., 2000

1375 Prud'homme and Kahn, 1996
Ripepe, 1996

1376

Ripepe and Goodeev, 1999

1377

Ripepe et al., 1996

1378

Ripepe et al., 2001

1379

Robertson et al., 1998

1380

Rowe et al., 2000

1381

Seidl et al., 1981

1382

Self et al., 1980

1383

1384

1385

1386

1387

1388

1389

\section{Acknowledgements}

1390

We thank Milton Garcès for taking the initiative to install a pressure sensor at Shishaldin. We are grateful for the support of the Alaska Volcano Observatory, as well as the insights of our colleagues, notably P. Stelling and S.R. McNutt. We thank Dan Osborne, Jay Helmericks, Steve Estes, Tanja Petersen and Guy Tytgat of the Geophysical Institute, UAF for help in retrieving and attempting to calibrate the pressure sensor. We also thank Matthias Hort and two anonymous reviewers whose comments greatly improved the quality of this manuscript. This work was supported by CNRS-INSU (ACI and PNRN: contribution number 323) and by the French Ministère de l'Environnement (number 122/2000). This is a IPGP contribution number 1945 .

1391

1392

1393

1394

1395

1396

1397

1398

1399

1400

1401

1402

1403

1404

1405

\section{References}

1406

Allard, P., 1997. Endogeneous magma degassing and storage at Mount Etna. Geophys. Res. Lett. 24, 2219-2222.

Allard, P., Carbonelle, J., Metrich, N., Loyer, H., 1994. Sulphur output and magma degassing budget of Stromboli volcano. Nature $368,326-330$.

Arciniega-Ceballos, A., Chouet, B., Dawson, P., 1999. Very longperiod signals associated with vulcanian explosions at Popocatepetl volcano, Mexico. Geophys. Res. Lett. 26 (19), 3013-3016.

Batchelor, G.K., 1967. An Introduction To Fluid Dynamics. Cambridge Univ. Press. 615 pp.

Beget, J., Nye, C., Stelling, P., 1998. Postglacial collapse and regrowth of Shishaldin volcano, Alaska, based on historic and prehistoric tephrochronology. Eos Trans. AGU 79, F979.
1407

1408

1409

1410

1411

1412

1413

1414

1415

1416

1417

1418

1419 
1420 Bikerman, J.J., 1973. Foams. Springer. 337 pp.

1421 Blackburn, E.A., Wilson, L., Sparks, R.S.J., 1976. Mechanics and 1422 dynamics of Strombolian activity. J. Geol. Soc. (London) 132, 1423 429-440.

1424 Buckingham, M.J., Garcès, M.A., 1996. A canonical model of 1425 volcano acoustics. J. Geophys. Res. 101, 8129-8151.

1426 Calvari, S., Coltelli, M., Muller, W., Pompillio, M., Scribano, V., 1427 1994. Eruptive history of the South-Eastern Crater of Mount 1428 Etna, from 1971 to 1994. Acta Vulcanol. 5, 11-14.

1429 Caplan-Auerbach, J., McNutt, S.R., 2003. New insights into the 14301999 eruption of Shishaldin volcano based on acoustic data. 1431 Bull. Volcanol. 65, 405-417.

1432 Chouet, B.A., 1996. New methods and future trends in seismolog1433 ical volcano monitoring. Monitoring and Mitigation of Volcano 1434 Hazards. Springer-Verlag, pp. 23-97.

1435 Chouet, B., Hamisevicz, N., McGetchin, T.R., 1974. Photoballistics 1436 of volcanic jet activity at Stromboli, Italy. J. Geophys. Res. 79, 1437 4961-4975.

1438 Chouet, B., Dawson, P., Ohminato, T., Martini, M., Saccorotti, G., 1439 Giudicepietro, F., De Luca, G., Milana, G., Scarpa, R., 2003. 1440 Source mechanisms of explosions at Stromboli volcano, Italy, 1441 determined from moment-tensor inversions of very-long-period 1442 data. J. Geophys. Res. 108 (B1), 2019;

1443 Chouet, B., Dawson, P., Ohminato, T., Martini, M., Saccorotti, G., 1444 Giudicepietro, F., De Luca, G., Milana, G., Scarpa, R., 2003. 1445 Source mechanisms of explosions at Stromboli volcano, Italy, 1446 determined from moment-tensor inversions of very-long-period 1447 data. ESE 7, 1-25.

1448 Cole, R.H., 1948. Underwater explosions. Princeton Univ. Press, 1449 Princeton, USA. 432 pp.

1450 Coltelli, M., Pompilio, M., Del Carlo, P., Calvari, S., Pannucci, S., 1451 Scribano, V., 1998. Etna: 1. Eruptive activity, ACVU, 26, 10, 1, 1452 141-148.

1453 Cruz, F.G., Chouet, B., 1997. Long-period events, the most char1454 acteristic seismicity accompanying the emplacement and extru1455 sion of lava dome in Galeras volcano, Columbia, in 1991.

1456 J. Volcanol. Geotherm. Res. 77, 121-158.

1457 Dehn, J., Dean, K.G., Engle, K., Izbekov, P., 2002. Thermal pre1458 cursors in satellite images of the 1999 eruption of Shishaldin 1459 volcano. Bull. Volcanol. 64, 525-534.

1460 Dingwell, D.B., 1998. Recent experimental progress in the phys1461 ical description of silicic magma relevant to explosive volca1462 nism. The physics of explosive volcanic eruptions. In: Gilbert, 1463 J.S., Sparks, R.S.J. (Eds.), Spec. Publ.-Geol. Soc., vol. 145, 1464 pp. 9-26.

1465 Dubosclard, G., Cordesses, R., Allard, P., Hervier, C., Coltelli, M., 1466 Kornprobst, J., 1999. First testing of a volcano Dopler radar 1467 (Voldorad) at Mount Etna, Italy. Geophys. Res. Lett. 26, $1468 \quad 3389-3392$.

1469 Dubosclard, G., Allard, P., Cordesses, R., Donnadieu, F., Hervier, 1470 C., Coltelli, M., Privitera, E., Kornprobst, J., 2003. Dopler 1471 radar sounding of volcanic eruption dynamics at Mount Etna. 1472 Bull. Volcanol. (submitted for publication).

1473 Eichelberger, J.C., Carigan, C.R., Westrich, H.R., Price, R.H., 1986.

1474 Non-explosive silicic volcanism. Nature 323, 598-602.

1475 Fabre, J., Linné, A., 1992. Modelling of two-phase slug flow. Annu. 1476 Rev. Fluid Mech. 24, 21-46.
Fournelle, J., 1988. The geology and petrology of Shishaldin volcano, Unimak Island, Aleutian Arc, Alaska. PhD Dissertation thesis, Johns Hopkins University. 507 pp.

Garcès, M.A., 1997. On the volcanic waveguide. J. Geophys. Res. 102 (B10), 22547-22564.

Garcès, M.A., 2000. Theory of acoustic propagation in a multiphase stratified liquid flowing within an elastic-walled conduit of varying cross-sectional area. J. Volcanol. Geotherm. Res. 101, $1-17$.

Garcès, M.A., Hansen, R.A., 1998. Waveform analysis of seismoacoustic signals radiated during the Fall 1996 eruption of Pavlof volcano, Alaska. Geophys. Res. Lett. 25 (7), 1051-1054.

Garcès, M.A., McNutt, S.R., 1997. Theory of the airborne sound field generated in a resonant magma conduit. J. Volcanol. Geotherm. Res. 78, 155-178.

Garcès, M.A., Hansen, R.A., Lindquist, K.G., 1998a. Traveltimes for infrasonic waves propagating in a stratified atmosphere. Geophys. J. Int. 135, 255-263.

Garcès, M.A., Hagerty, M.T., Schwartz, S.Y., 1998b. Magma acoustics and time-varying melt properties at Arenal volcano, Costa Rica. Geophys. Res. Lett. 25 (13), 2293-2296.

Garcès, M.A., McNutt, S.R., Hansen, R.A., Eichelberger, J.C., 2000. Application of wave-theoretical seismoacoustic models to the interpretation of explosion and eruption tremor signals radiated by Pavlof volcano, Alaska. J. Geophys. Res. 105 (B2), 3039-3058.

Garcès, M.A., Iguchi, M., Ishihara, K., Morrissey, M., Sudo, Y., Tsutsui, T., 2001. Infrasonic precursors to a Vulcanian eruption at Sakurajima volcano, Japan. Geophys. Res. Lett. 26 (16), $1071-1074$.

Hagerty, M.T., Schwartz, S.Y., Garcès, M.A., Protti, M., 2000. Analysis of seismic and acoustic observations at Arenal volcano, Costa Rica, 1995-1997. J. Volcanol. Geotherm. Res. 101, 27-65.

Hort, M., Seyfried, R., 1998. Volcanic eruption velocities measured with a micro radar. Geophys. Res. Lett. 25 (1), 113-116.

Ishihara, K., 1985. Dynamical analysis of volcanic explosion. J. Geodyn. 3, 327-349.

Jaupart, C., Vergniolle, S., 1988. Laboratory models of Hawaiian and Strombolian eruptions. Nature 331 (6151), 58-60.

Jaupart, C., Vergniolle, S., 1989. The generation and collapse of a foam layer at the roof of a basaltic magma chamber. J. Fluid Mech. 203, 347-380.

Johnson, J.B., 2003. Generation and propagation of infrasonic airwaves from volcanic explosions. J. Volcanol. Geotherm. Res. $121,1-14$.

Johnson, J.B., Lees, J.M., 2000. Plugs and chugs: seismic and acoustic observations of degassing explosions at Karymsky, Russia and Sangay, Ecuador. J. Volcanol. Geotherm. Res. 101, 67-82.

Johnson, J.B., Lees, J.M., Gordeev, E.I., 1998. Degassing explosions at Karymsky volcano, Kamchatka. Geophys. Res. Lett. 25, 3999-4002.

Kieffer, S.W., 1981. Fluid dynamics of the May 18 blast at Mount St. Helens. U.S. Geol. Surv. Prof. Pap. 1250, 379.

Kirpatrick, R.D., Lockett, M.J., 1974. The influence of the approach velocity on bubble coalescence. Chem. Eng. Sci. 29, 2363-2373.
1477

1478

1479

1480

1481

1482

1483

1484

1485

1486

1487

1488

1489

1490

1491

1492

1493

1494

1495

1496

1497

1498

1499

1500

1501

1502

1503

1504

1505

1506

1507

1508

1509

1510

1511

1512

1513

1514

1515

1516

1517

1518

1519

1520

1521

1522

1523

1524

1525

1526

1527

1528

1529

1530

1531

1532

1533 
1534 Landau, L.D., Lifshitz, E.M., 1986. Course in Theoretical Physics: 1535 Theory of Elasticity, vol. 7. Pergamon Press, Oxford. 187 pp. 1536 Landau, L.D., Lifshitz, E.M., 1987. Course in Theoretical Physics: 1537 Fluids Mechanics, vol. 6. Pergamon Press, Oxford. 536 pp. 1538 Le Guern, F., Tazieff, H., Vavasseur, C., Zettwoog, P., 1982. 1539 Resonance in gas discharge of the Bocca Nuova, Etna (Italy, 1540 1968-1969). J. Volcanol. Geotherm. Res. 12, 161-166.

1541 Leighton, T.G., 1994. The Acoustic Bubble. Academic press, Lon1542 don. 613 pp.

1543 Lighthill, J., 1978. Waves in Fluids. Cambridge Univ. Press. 504 pp. 1544 McGetchin, T.R., Settle, M., Chouet, B.A., 1974. Cinder cone 1545 growth modeled after northeast crater, Mount Etna, Sicily. 1546 J. Geophys. Res. 79 (23), 3257-3272.

1547 McNutt, S.R., 2000. Volcanic seismicity. In: Sigurdsson, H., 1548 Houghton, B., McNutt, S.R., Rymer, H., Stix, J. (Eds.), Chapter 154963 of Encyclopedia of Volcanoes. Academic Press, San Diego, 1550 pp. $1015-1033$.

1551 Morrissey, M.M., Chouet, B., 1997a. A numerical investigation of 1552 choked flow dynamics and its application to the triggering 1553 mechanism of long-period events at Redoubt volcano, Alaska. 1554 J. Geophys. Res. 102 (B4), 7965-7983.

1555 Morrissey, M.M., Chouet, B., 1997b. Burst conditions of explosive 1556 volcanic eruptions recorded on microbarographs. Science 275, 1557 1290-1293.

1558 Neuberg, J., Luckett, R., Bapti, B., Olsen, K., 2000. Models of 1559 tremor and low-frequency swarms on Montserrat. J. Volcanol. 1560 Geotherm. Res. 101, 83-104.

1561 Nye, C.J., Keith, T., Eichelberger, J.C., Miller, T.P., McNutt, S.R., 1562 Moran, S.C., Schneider, D.J., Dehn, J., Schaefer, J.R., 2002. The 15631999 eruption of Shishaldin volcano, Alaska: monitoring a dis1564 tant eruption. Bull. Volcanol. 64, 507-519.

1565 Plesset, M.S., Mitchell, T.P., 1956. On the stability of the spherical

1566 shape of a vapor cavity in liquid. Q. Appl. Math. 13, 419-430.

1567 Plesset, M.S., Prosperetti, A., 1977. Bubble dynamics and cavita-

1568 tion. Annu. Rev. Fluid Mech. 9, 145-185.

1569 Prosperetti, A., 1986. Bubble dynamics. Proc. Int. Sch. Phys.

1570 "Enrico Fermi" XCIII, 145-188.

1571 Proussevitch, A.A., Kutolin, V.A., 1986. Surface tension of mag1572 matic melts. Geol. Geophys. 9, 58-67 (in Russian).

1573 Proussevitch, A.A., Sahagian, D.L., 1996. Dynamics of coupled 1574 diffusive and decompressive bubble growth in magmatic sys1575 tems. J. Geophys. Res. 101 (B8), 17447-17455.

1576 Prud'homme, R.K., Kahn, S.A., 1996. Foams: Theory, Measure1577 ments, and Applications. Marcel Dekker, New York. 590 pp.

1578 Richards, A.F., 1963. Volcanic sounds, investigation and analysis.

1579 J. Geophys. Res. 68, 919-928.

1580 Richter, D.H., Eaton, J.P., Murata, K.J., Ault, W.U., Krivoy, H.L., 1581 1970. Chronological narrative of the 1959-60 eruption of 1582 Kilauea volcano, Hawaii. U.S. Geol. Surv. Prof. Pap. 537, $1583 \quad 1-70$.

1584 Ripepe, M., 1996. Evidence for gas influence on volcanic seismic 1585 signals recorded at Stromboli. J. Volcanol. Geotherm. Res. 70, $1586221-233$.

1587 Ripepe, M., Gordeev, E., 1999. Gas bubble dynamics model for 1588 shallow volcanic tremor at Stromboli. J. Geophys. Res. 104 1589 (B5), 10639-10654.

1590 Ripepe, M., Rossi, M., Saccarotti, G., 1993. Image processing of explosive activity at Stromboli. J. Volcanol. Geotherm. Res. 54, $335-351$.

Ripepe, M., Poggi, P., Braun, T., Gordeev, E., 1996. Infrasonic waves and volcanic tremor at Stromboli. Geophys. Res. Lett. 23 (2), 181-184.

Ripepe, M., Coltelli, M., Privitera, E., Gvresta, S., Moretti, M., Piccinini, D., 2001. Seismic and infrasonic evidences for an impulsive source of the shallow volcanic tremor at Mt. Etna, Italy. Geophys. Res. Lett. 28 (6), 1071-1074.

Robertson, R., Cole, P., Sparks, R.S.J., Harford, C., Lejeune, A.M., McGuire, W.J., Miller, A.D., Murphy, M.D., Norton, G., Stevens, N.F., Young, S.R., 1998. The explosive eruption of Soufriere Hills Volcano, Montserrat, West Indies, 17 September, 1996. Geophys. Res. Lett. 25 (18), 3429-3432.

Rowe, C.A., Aster, R.C., Kyle, P.R., Dibble, R.R., Schlue, J.W., 2000. Seismic and acoustic observations at Mount Erebus Volcano, Ross Island, Antartica, 1994-1998. J. Volcanol. Geotherm. Res. 101, 105-128.

Seidl, D., Schick, R., Riuscetti, M., 1981. Volcanic tremor at Etna: a model for hydraulic origin. Bull. Volcanol. 44, 43-56.

Self, S., Sparks, R.S.J., Booth, B., Walker, G.P.L., 1974. The 1973 Heimaey Strombolian scoria deposit, Iceland. Geol. Mag. 111 (6), 539-548.

Self, S., Kienle, J., Huot, J.P., 1980. Ukinrek maars, Alaska: 2. Deposits and formation of the 1977 craters. J. Volcanol. Geotherm. Res. 7, 39-65.

Sparks, R.S.J., Bursik, M.I., Carey, S.N., Gilbert, J.S., Glaze, L.S., Sigurdsson, H., Woods, A.W., 1997. Volcanic Plumes. Wiley. 574 pp.

Stelling, P., Beget, J., Nye, C., Gardner, J., Devine, J.D., George, R.M.M., 2002. Geology and petrology of ejecta from the 1999 eruption of Shishaldin volcano, Alaska. Bull. Volcanol. 64, $548-561$.

Swanson, D.A., Holcomb, R.T., 1990. Regularities in growth of Mount Saint Helens dacite dome; 1980-1986. Proc. Volcanol. 2, 1-24.

Temkin, S., 1981. Elements of Acoustics. Wiley. 515 pp.

Thompson, G., McNutt, S.R., Tytgat, G., 2002. Three distinct regimes of volcanic tremor associated with the eruption of Shishaldin volcano, Alaska, April 1999. Bull. Volcanol. 64, 535-547.

Uhira, K., Takeo, M., 1994. The source of explosive eruptions of Sakurajima volcano, Japan. J. Geophys. Res. 99 (B9), $17775-17789$.

Vergniolle, S., 1998. Modelling two-phase flow in a volcano. Proc. of 13th Australasian Fluid Mech. Conf., pp. 647-650. Melbourne.

Vergniolle, S., 2001. Listening to Stromboli volcano as a tool into its volcanic conduit. Eos Trans. AGU 82 (47), F1399.

Vergniolle, S., 2003. Listening to volcanoes as a tool to understand eruption dynamics: Etna (Italy), Shishaldin (Alaska). IUGG Proc., pp. 131-138. Sapporo, Japan.

Vergniolle, S., Brandeis, G., 1994. Origin of the sound generated by Strombolian explosions. Geophys. Res. Lett. 21, 1959-1962.

Vergniolle, S., Brandeis, G., 1996. Strombolian explosions: a large bubble breaking at the surface of a lava column as a source of sound. J. Geophys. Res. 101 (B9), 20433-20448.
1591

1592

1593

1594

1595

1596

1597

1598

1599

1600

1601

1602

1603

1604

1605

1606

1607

1608

1609

1610

1611

1612

1613

1614

1615

1616

1617

1618

1619

1620

1621

1622

1623

1624

1625

1626

1627

1628

1629

1630

1631

1632

1633

1634

1635

1636

1637

1638

1639

1640

1641

1642

1643

1644

1645

1646

1647 
1648 Vergniolle, S., Caplan-Auerbach, J., 2003a. Acoustic measurements 1649 of the 1999 basaltic eruption of Shishaldin volcano, Alaska: 2) 1650 Precursor to the Subplinian activity. J. Volcanol. Geotherm. Res. 1651 (this issue).

1652 Vergniolle, S., Caplan-Auerbach, J., 2003b. Basaltic and Subplinian 1653 plumes: constraints from acoustic measurements at Shishaldin 1654 volcano, Alaska. Earth Planet Sci. Lett., Subm. 3.

1655 Vergniolle, S., Caplan-Auerbach, J., 2003c. Acoustic measurements 1656 of a Subplinian basaltic eruption: Shishaldin volcano, Alaska, 1657 1999. J. Geophys. Res. 4.

1658 Vergniolle, S., Caplan-Auerbach, J., 2003d. Chronicle of an explo1659 sive basaltic eruption from the sound produced by the 1999 1660 Shishaldin eruption, Alaska. J. Geophys. Res., Subm. 5.

1661 Vergniolle, S., Jaupart, C., 1986. Separated two-phase flow and 1662 basaltic eruptions. J. Geophys. Res. 91 (B12), 12842-12860.

1663 Vergniolle, S., Jaupart, C., 1990. The dynamics of degassing at 1664 Kilauea volcano, Hawaii. J. Geophys. Res. 95 (B3), 2793-2809. 1665 Vergniolle, S., Brandeis, G., Mareschal, J.C., 1996. Strombolian 1666 explosions: eruption dynamics determined from acoustic meas1667 urements. J. Geophys. Res. 101 (B9), 20449-20466.

1668 Walker, G.P.L., Croasdale, R., 1970. Two plinian-type eruptions in 1669 the Azores. Q. J. Geol. Soc. Lond. 127, 17-55.

1670 Wallis, G.B., 1969. One Dimensional Two-Phase Flows. Mc Graw 1671 Hill. 408 pp.
Weill, A., Brandeis, G., Vergniolle, S., Baudin, F., Bilbille, J., Fevre, J.-F., Piron, B., Hill, X., 1992. Acoustic sounder measurements of the vertical velocity of volcanic jets at Stromboli volcano. Geophys. Res. Lett. 19, 2357-2360.

Wiemer, S., McNutt, S.R., 1997. Variations in the frequency-magnitude distribution with depth in two volcanic areas: Mount St Helens, Washington and Mt Spurr, Alaska. Geophys. Res. Lett. 24, 189-192.

Williams, S.N., 1983. Plinian airfall deposits of basaltic composition. Geology 11, 211-214.

Williams, H., McBirney, A.R., 1979. Volcanology, Freeman Cooper. 397 pp.

Wilson, L., 1972. Explosive volcanic eruptions: 2. The Atmospheric trajectories of pyroclasts. Geophys. J. R. Astr. Soc. 30, 381-392.

Wilson, L., 1980. Relationships between pressure, volatile content and ejecta velocity. J. Volcanol. Geotherm. Res. 8, 297-313.

Wilson, L., Head, J.W., 1981. Ascent and eruption of basaltic magma on the earth and moon. J. Geophys. Res. 86, 2971-3001.

Wohletz, K., 2001. Kware Magma v. 2.44.0079, 2001.

Wolfe, E.W., Garcia, M.O., Jackson, D.B., Koyanagi, R.Y., Neal, C.A., Okamura, A.T., 1987. The Puu O'o eruption of Kilauea volcano, episodes 1-20, January 3, 1983 to June 8, 1984. U.S. Geol. Surv. Prof. Pap. 1350, 471-508.
1672

1673

1674

1675

1676

1677

1678

1679

1680

1681

1682

1683

1684

1685

1686

1687

1688

1689

1690

1691

1692

1693

1694 